\title{
TITLE:
}

\section{INVERTEBRATE FAUNA OF THE INTERTIDAL ZONE OF THE TOKARA ISLANDS -XIII. ANOMURA-}

\author{
$\operatorname{AUTHOR}(\mathrm{S})$ :
}

Miyake, Sadayoshi

\section{CITATION:}

Miyake, Sadayoshi. INVERTEBRATE FAUNA OF THE INTERTIDAL ZONE OF THE TOKARA ISLANDS -XIII. ANOMURA-. PUBLICATIONS OF THE SETO MARINE BIOLOGICAL LABORATORY 1956, 5(3): 303-337

ISSUE DATE:

$1956-12-20$

URL:

http://hdl.handle.net/2433/174568

RIGHT: 


\title{
INVERTEBRATE FAUNA OF THE INTERTIDAL ZONE OF THE TOKARA ISLANDS
}

\author{
XIII. ANOMURA ${ }^{12 \text { 2) }}$ \\ SADA YOSHI MIYAKE \\ Zoological Laboratory, Faculty of Agriculture, \\ Kyushu University, Fukuoka
}

With 23 Text-figures

The biological expedition of the Osaka Municipal Museum of Natural History to the Tokara Islands, Kagoshima Prefecture was made during the period from May 25 to June 13, 1953.

I shall here report the Anomuran Crustacea collected by Dr. Takasi Tokioka of the Seto Marine Biological Laboratory and Mr. Shoichi Miyamoto of the Biological Laboratory, Kyushu University. The examination has revealed that these specimens fall in 15 species of five genera as listed below.

1. Callianidea typa H. Milne Edwards

2. Petrolisthes japonicus (DE HAAN)

*3. Petrolisthes unilobatus Henderson

4. Petrolisthes hastatus STIMPSON

5. Petrolisthes tomentosus (DANA)

*6. Clibanarius eurysternus HILGENDORF

7. Clibanarius corallinus (H. MILNE EDWARDS)

8. Clibanarius virescens (KRAuss)

*9. Clibanarius zebra rhabdodactylus Forest

10. Calcinus elegans (H. Milne EDwards)

11. Calcinus laevimanus (RANDALL)

12. Calcinus gaimardi (H. Mine Edwards)

*13. Calcinus terrae-reginae HASwELL

14. Calcinus latens (RANDALL)

15. Coenobita rugosus H. Milne Edwards

All of these species are unrecorded from Tokara Islands and four of them marked

1) Scientific Survey of the Tokara Islands, Report No. 30.

2) Contributions from the Zoological Laboratory, Faculty of Agriculture, Kyushu University, No. 229.

Publ. Seto Mar. Biol. Lab., V (3), 1956. (Article 19) 
with an asterisk are new to the Japanese fauna.

I am especially indebted to Prof. Dr. Y. K. Hiraiwa of the Zoological Laboratory, Faculty of Agriculture, Kyushu University who has provided facilities require for the pursuit of this work. I express my hearty thanks to Dr. T. TокіоKA and Mr. S. Miуамото, for placing materials at my disposal. Acknowledgment is also due to Dr. H. UTinomi of the Seto Marine Biological Laboratory, for his suggestions and sending me valuable papers not accessible to me.

\section{Family CALLIANASSIDAE BATE, 1888}

\section{Callianidea typa $\mathrm{H}$. Milne Edwards, 1837}

(Figs. 1-3)

New Japanese name: Erage-sunamoguri

Callianidea typa H. Milne Edwards 1837, p. 320, pl. 25, f. 8-10-Bismark Is. (type-locality). BORRADAILE 1898, p. 1015-Funafuti, Ellice Is. DE MAN 1902, p. 751-Ternate.

BORRADAILE 1906, p. 752-Maldive Is. NoBILI 1906, p. 113-Red Sea.

Pesta 1914, p. 678-Samoa.

BALss 1914, p. 90-Tonga, E. Africa ; Kagoshima ; Yaéyama I.

Description. A female $38 \mathrm{~mm}$ in body-length from Takara-jima. Carapace much compressed, smooth, glabrous, nearly one-fourth of total length of the body; rostrum small, a little produced; the cervical groove and linea thalassinica distinct.

Eye-stalk $0.7 \mathrm{~mm}$ long, broad, much depressed, divergent proximally, and longer than first joint of antennal peduncle. Eye small, being situated on the outer side of the stalk. Antennule with biramous flagellae, each of them nearly equal, $7 \mathrm{~mm}$ long, one of these about 20-jointed with long, soft hairs only on one side, the other without hairs, about 30-jointed; its basal peduncle $3.6 \mathrm{~mm}$ long, with three joints; first joint $1.3 \mathrm{~mm}$ long containing otholith, a little longer than the second $(1 \mathrm{~mm})$, and equals to the third. Antennal peduncle $4.4 \mathrm{~mm}$ long, slender, four-jointed, 1, 3,6 and 3 in the relative lengths; the flagellum of antenna $12 \mathrm{~mm}$ long, about 50-jointed, a little longer than 2.5 times as long as the peduncle.

Thoracic legs smooth, glabrous. Chelipeds unequal, with long hairs or setae on the margins; the right cheliped longer than the left one; ischium $5 \mathrm{~mm}$ long, rather slender, divergent distally; arm spindle-shaped, much swollen in the middle, and equals in length to ischium; wrist $1.8 \mathrm{~mm}$ long, very short, about twice as broad as long, divergent distally; palm $5.6 \mathrm{~mm}$ long, much compressed, very long, about three times as long as wrist; its posterior margin bears about 15 spinules; the immovable and movable fingers with two or three small teeth on the cutting margins, but their outer margins with long hairs; movable finger $5.6 \mathrm{~mm}$ long, much curved inwards, so that tips of fingers cross over to each other. The left cheliped rather slender, 


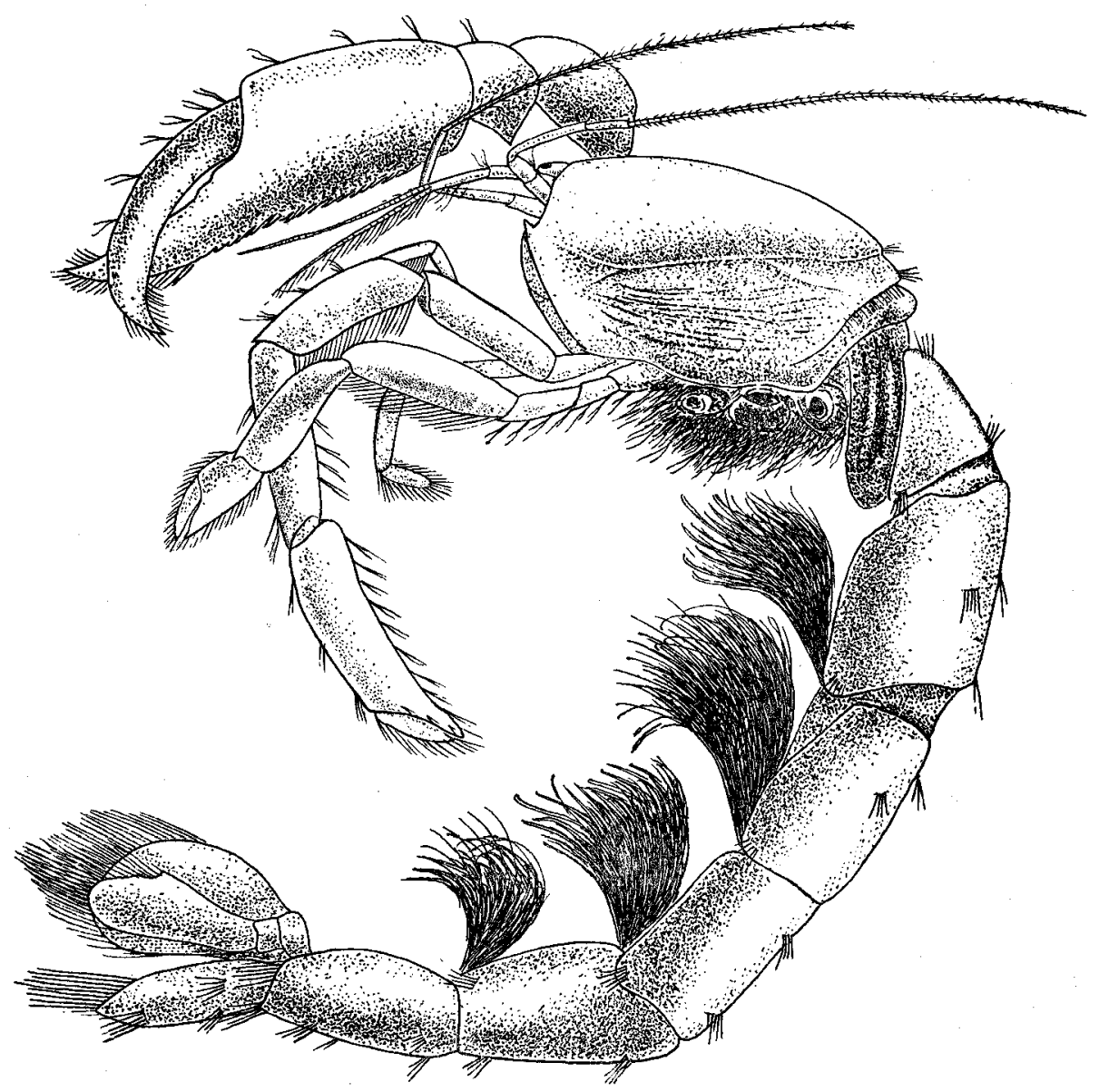

Fig. 1. Lateral view of Callianidea typa H. Mune Edwards, $\times 5$.

much compressed; arm $3.5 \mathrm{~mm}$ long, a little shorter than ischium ( $4 \mathrm{~mm}$ ), its upper margin with three tufts of hairs, but the lower distal margin beset with short hairs; the lower margins of wrist and palm bear fine, closely-set tufts of hairs; the upper margins of palm and movable finger with long hairs thickly.

Second thoracic leg chelate, $13 \mathrm{~mm}$ in whole length; upper and lower margins of all joints, except on upper margin of merus, with soft, long hairs thickly; proportions of dactylus, carpus, merus and ischium are $10: 9: 12: 27: 7$. The third leg $13 \mathrm{~mm}$, subchelate, same length of second one; dactylus $1.5 \mathrm{~mm}$ long, rather small, articulated with propodus at the middle of the distal margin; propodus $3 \mathrm{~mm}$ long, very broad, almost as broad as long, with scattered tufts of short hairs on outer surface, with long hairs on distal and lower margins, armed with an acute tooth on inner distal angle forming a small cheliped with the dactylus; carpus $2.7 \mathrm{~mm}$ long, divergent distally, with three tufts of hairs, two of them on upper margin, the other 


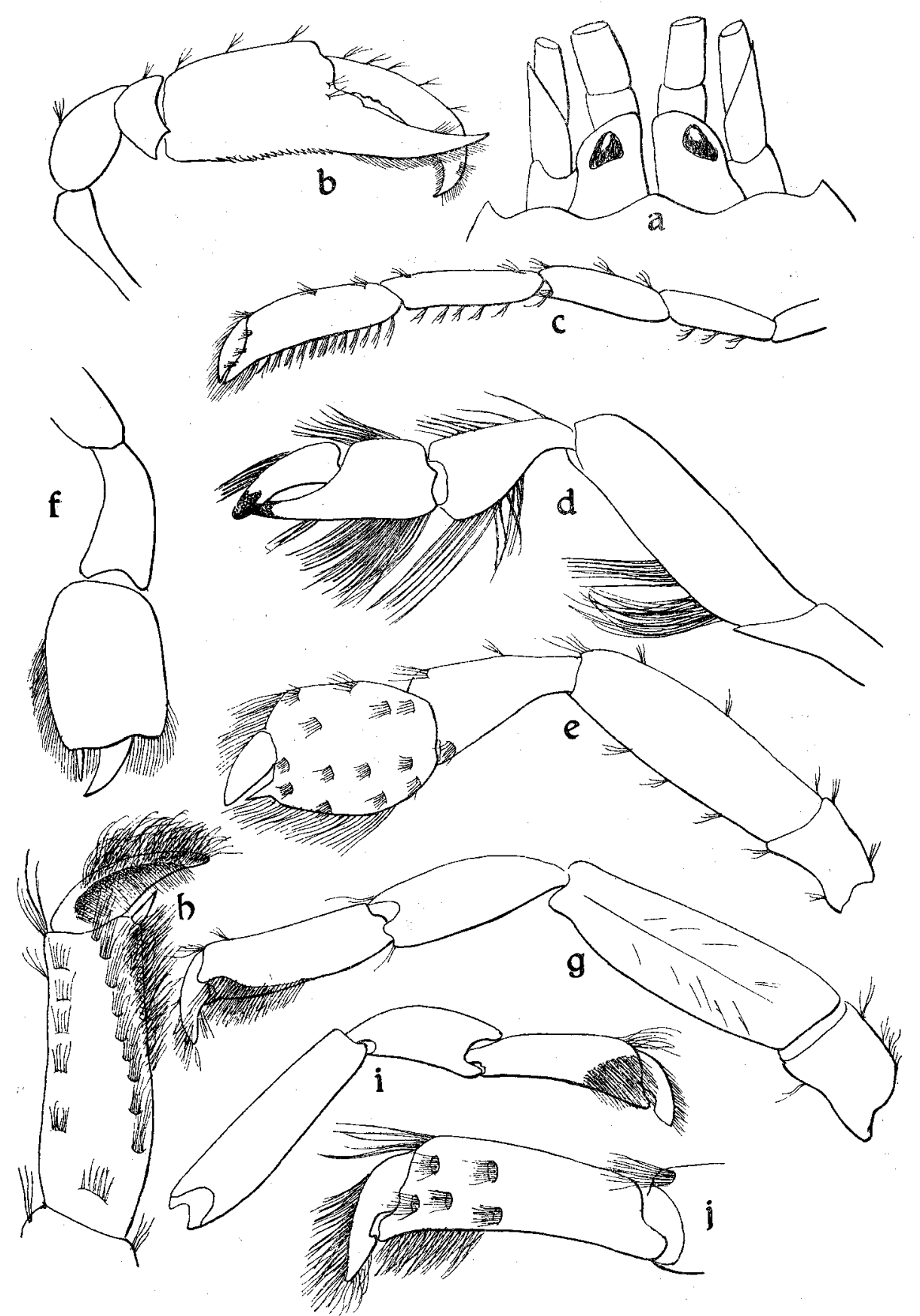

Fig. 2. Callianidea typa H. Milne Edwards.

a, Upper view of frontal region, $\times 14$. b, outer view of right cheliped, $\times 4$. c, outer view of left cheliped, $\times 4$. d, upper view of left second leg, $\times 7$. e, upper view of left third leg, $\times 7$. f, lower view of tip of the same, $\times 7$. $g$, lower view of right fourth leg, $\times 7$. h, upper view of tip of the same, $\times 14$. $\mathrm{i}$, lower view of right fourth leg, $\times 7$. j, upper view of tip of the same, $\times 14$. 


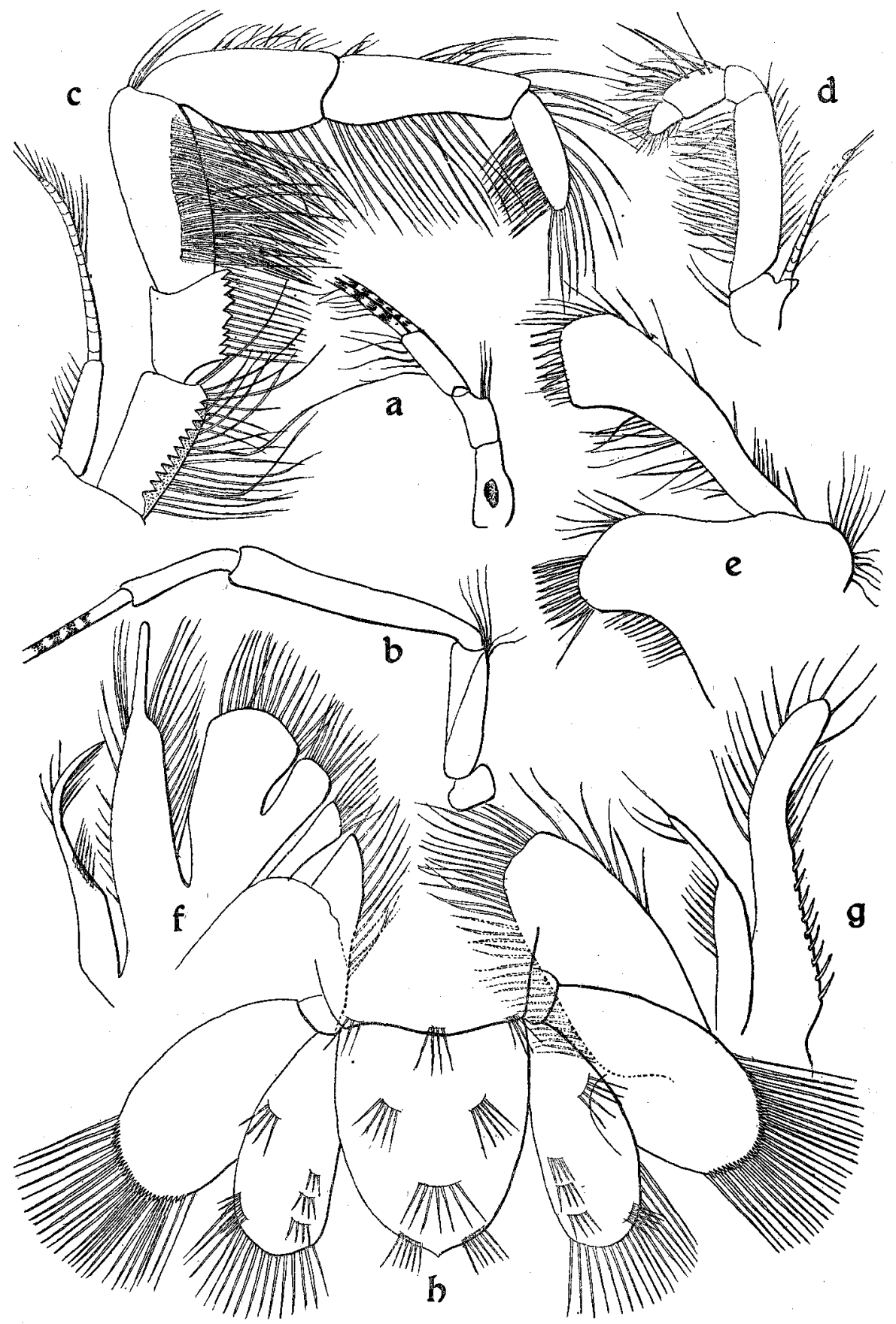

Fig. 3. Callianidea typa H. MILNE EDwards.

a, Peduncle of antennule, $\times 10$. b, basal peduncle of antenna, $\times 14$, c, lower view of left third maxilliped, $\times 14$. d, upper view of left second maxillped, $\times 14$. e, upper view of left first maxilliped, $\times 30$. $\mathrm{f}$, upper view of left second maxilla, $\times 30$. $\mathrm{g}$, upper view of left first maxilla, $\times 30$. h, upper view of telson and uropods. $\times 7$. 
on lower distal angle; merus $5.1 \mathrm{~mm}$ long, with seven tufts of hairs, four of them on upper margin, while three on lower one; ischium $1.7 \mathrm{~mm}$ long, with two tufts of hairs on both upper and lower margins.

Fourth and fifth legs normal. Fourth leg $15 \mathrm{~mm}$ long, longer than the fifth leg; dactylus $1.7 \mathrm{~mm}$ long, ornamented on both upper and lower surfaces with long hairs thickly; propodus $3.4 \mathrm{~mm}$ long, twice as long as dactylus, equal in length to carpus, but about two-thirds as long as merus $(5.2 \mathrm{~mm})$; the outer surface of propodus with two rows of tufts of hairs, the inner (or ventral) surface with a row of closely-set hairs on distal half of posterior margin; in addition to propodus bears a prominent spine on the lower distal angle. Fifth leg $13.5 \mathrm{~mm}$ long; dactylus $1.7 \mathrm{~mm}$ long, with long hairs thickly; propodus $3.3 \mathrm{~mm}$ long, almost twice as long as dactylus, its outer surface with scattered tufts of short hairs on distal one-third of the segment, its inner surface with setae at distal part; propodus and carpus bear a group of long hairs on outer distal angle; merus $4.3 \mathrm{~mm}$ long, without hairs; ischium $1.5 \mathrm{~mm}$ long.

Maxillipeds and maxillae are figured in the Fig. $3 \mathrm{c}-\mathrm{g}$. Abdomen glabrous, compressed; its dorsal surface with tufts of setae. Uropods longer than telson. First pleopod small, tapering; second to fifth pleopods attached to gill-filaments.

Colour in alcohol. Body white; legs and gill-filaments cream-yellow.

Material examined. 1 \& (TK. No. 562), Takara-jima, May 25-June 1, 1953, collected by Tokioka.

Distribution. Widely distributed in the Indo-Pacific Ocean from Red Sea and E. Africa to Polynesia and Japan. Since this species has been recorded from Kagoshima by BALss (1914), it is the northern-most locality.

\section{Family PORCELLANIDAE DANA, 1858}

\section{Genus Petrolisthes STIMPSON, 1858}

Diagnosis. Carapace depressed, subovate; front triangular, margin more or less undulated, toothed or entire. Epimera entire. Eyes rather large. First (basal or coxal) peduncle of antenna remarkably short, not reaching the upper margin of carapace; second (movable) peduncle of the same flattened, more or less cristate. Chelipeds equal or subequal, broad and flattened; wrist slightly elongated, often provided with teeth on anterior margin. Ambulatory legs with dactylus short and robust, terminating in a single claw.

Four species were taken in the Tokara Islands.

Key to the species of Petrolisthes

1 Epibranchial spine present. Carapace and legs sparsely tomentose. Wrist with saw-shaped teeth on anterior margin. Propodus of first three ambulatory legs with four spinules

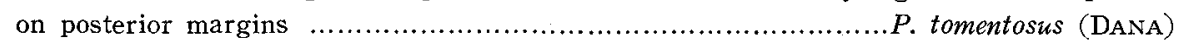

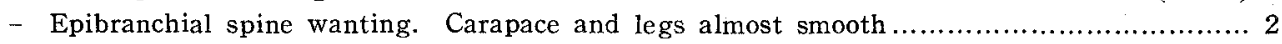

2 Posterior margin of wrist with two or three teeth. Propodus of first three ambulatory 
legs with five spinules on posterior margin P. japonicus (DE HAAN)

- Posterior margin of wrist prolonged at distal end into acute spine

3 Wrist with a single tooth at the proximal end .P. unilobatus HENDERSON

- Wrist with three teeth on anterior margin P. hastatus STIMPSON

\section{Petrolisthes japonicus (DE HAAN, 1849)}

Jap. name: Iso-kanidamashi

Porcellana japonica DE HAAN 1849, p. 199, pl. 50, f. 5-Japan.

Petrolisthes japonicus MrYake 1943, p. 73, f. 11-13 (Synonymy).

Material examined. $1 \hat{\delta}$ (TK. No. 563 ) (c. $1 .=8.2 \mathrm{~mm} ;$ c. b. $=7.9 \mathrm{~mm}$ ), Nakanoshima, May 25, June 3-13, 1953 (TокıокA).

Distribution. Borneo, Malacca, Mergui Is., Hongkong, Bonin Is., Ryukyu and Japan. Commonly found under stones in Japan.

\section{Petrolisthes unilobatus Henderson, 1888}

New Jap. name; Togenashi-kanidamashi

Petrolisthes unilobatus Henderson 1888, p. 106, pl. 11, f. 3, 3a-Off Nukalofa, Tongatabu Is. (type-locality).

Petrolisthes unilobatus Mtyake 1943, p. 66, f. 7, 8 (Formosa, Ryukyu).

Colour in alcohol. Dorsal surface of the carapace and legs reddish; the ventral surface of a white colour.

Material examined. $3 \hat{o}$ ô, 1 ovig. 우 (TK. No. 564), Nakano-shima, May 25, June 3-13, 1953 (ToKioKa).

Dimensions (in $\mathrm{mm}$ ).

$\begin{array}{lcccc} & \hat{\delta} & \hat{\delta} & \hat{\delta} & \text { ovig. 우 } \\ \text { c. 1. } & 5.6 & 6.8 & 8.0 & 6.5 \\ \text { c. b. } & 5.6 & 6.7 & 7.3 & 6.5\end{array}$

Distribution. Tongatabu Is., Formosa and Okinawa-Hontō, Ryukyu. Nakano-shima Islet is the northern limit of this species. And this is the first record from Japan.

\section{Petrolisthes hastatus Stimpson, 1858}

Jap. name: Minami-kanidamashi

Petrolisthes hastatus STIMPSON 1858, p. 79 ; 1907, p. 184, pl. 22, f. 4-Kikai-jima ; Amami-Oshima. Petrolisthes hastatus MrYAKE 1943, p. 62, f. 5-6 (Synonymy).

Petrolisthes hastatus MIYAKE 1949, p. 742, f. 2146.

Material examined: 2 옹 8,2 우, 2 ovig. 우 우 (TK. No. 565), Takara-jima, May 26-June 1, 1953 (TokiokA). 
Dimensions (in $\mathrm{mm}$ ).

\begin{tabular}{|c|c|c|c|c|c|c|}
\hline & 잉 & $\beta$ & 우 & 우 & ovig. ㅇ & ovig. \\
\hline & 6.5 & 8.3 & 6.2 & 6.6 & 7.5 & 10.9 \\
\hline & 6.4 & 8.0 & 6.0 & 6.6 & 7.0 & 11.5 \\
\hline
\end{tabular}

Distribution. From Nicobars to Bismark Islands. Takaranjima is the northern limit of this species.

\section{Petrolisthes tomentosus (DANA, 1852)}

Jap. name: Kebuka-kanidamashi

Porcellana tomentosa DANA 1852, p. $420 ; 1855$, pl. 26, f. 10-Raraka I., Paumotu Is. (type-locality). Petrolisthes tomentosus MiYake 1943, p. 85, f. 19-21 (Synonymy).

Petrolisthes tomentosus MrYake 1949, p. 742, f. 2147.

Material examined. 1 ovig. 우 (TK. No. 566) (c. $1 .=6.8 \mathrm{~mm}, \quad$ c. b. $=6.8 \mathrm{~mm}$ ), Nakano-shima, May 25, June 3-13, 1953 (TokiokA).

Distribution. Paumotu Is., Bonin Is., Ryukyu (Ishigaki-jima), Amami-Oshima, Meshima Islet, Danjo-Group (northern limit) and above-mentioned locality.

Family PAGURIDAE DANA, 1852

\section{Clibanarius eurysternus HILGENDORF, 1878}

(Figs. 4-5)

New Jap. name: Hirakō-yokobasami

Pagurus (Clibanarius) eurysternus HILGENDORF 1878, Monatsb. Akad. Wissensch., p. 822, pl. 3 , f. 9-10-Mozanbique, E. Africa (type-locality) (not seen).

Clibanarius eurysternus FiZE et SERÈne 195E. p. 118, f. 17 (Synonymy).

Description. The coxae of fifth thoracic legs, owing to depressed and deflexed carapace, are wide apart. This peculiar form of the carapace is a special adaptation for the occupation of the narrow cavities of shell of the Strombidae. It is easily distinguished from other members of the genus by the flattened carapace.

Eye-stalk excluding eye a little shorter than anterior border of carapace, but distinctly longer than antennal peduncle. Antennal acicle armed with four spinules, one of them on the outer and three on the inner margins. It reaches one-third of the last joint of antennal peduncles.

Cheliped subequal, spinulose, setose; arm with two acuminate teeth on upper outer margin; wrist with one spine on upper inner margin; palm a little shorter than fingers, provided on upper surface with thorn-like tubercles and hairs; of which four or five tubercles on inner border and five ones on inner margin of immovable finger are most prominent. Fingers with three teeth on each cutting margin, two of them on the proximal part small, but the other on the distal part large. 


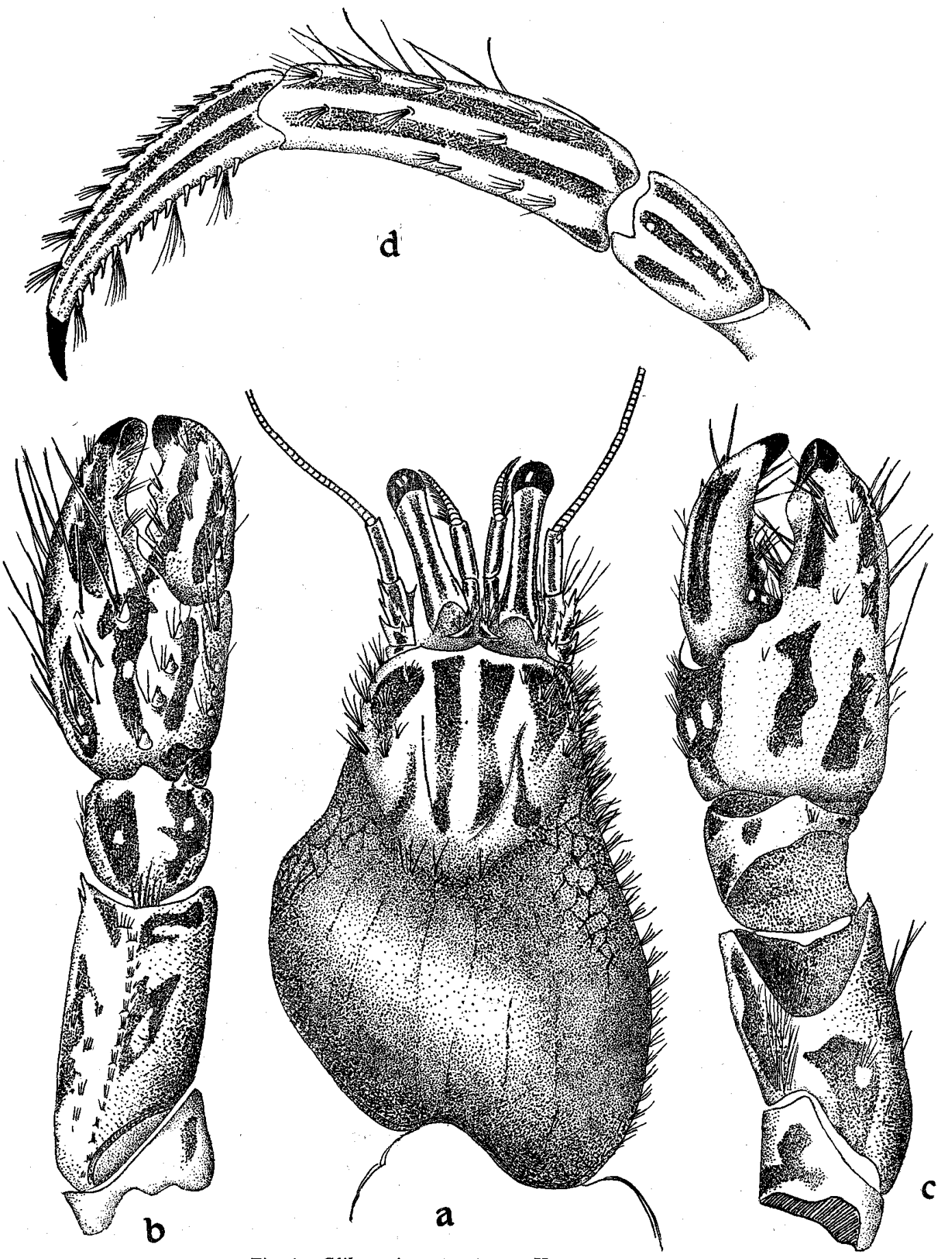

Fig 4. Clibanarius eurysternus HILGENDORF.

a, Upper view of cephalothorax, $\times 8$. b. upper view of left cheliped, $\times 16$. c, lower view of the same, $\times 16$. $d$, outer view of left third leg, $\times 10$. 

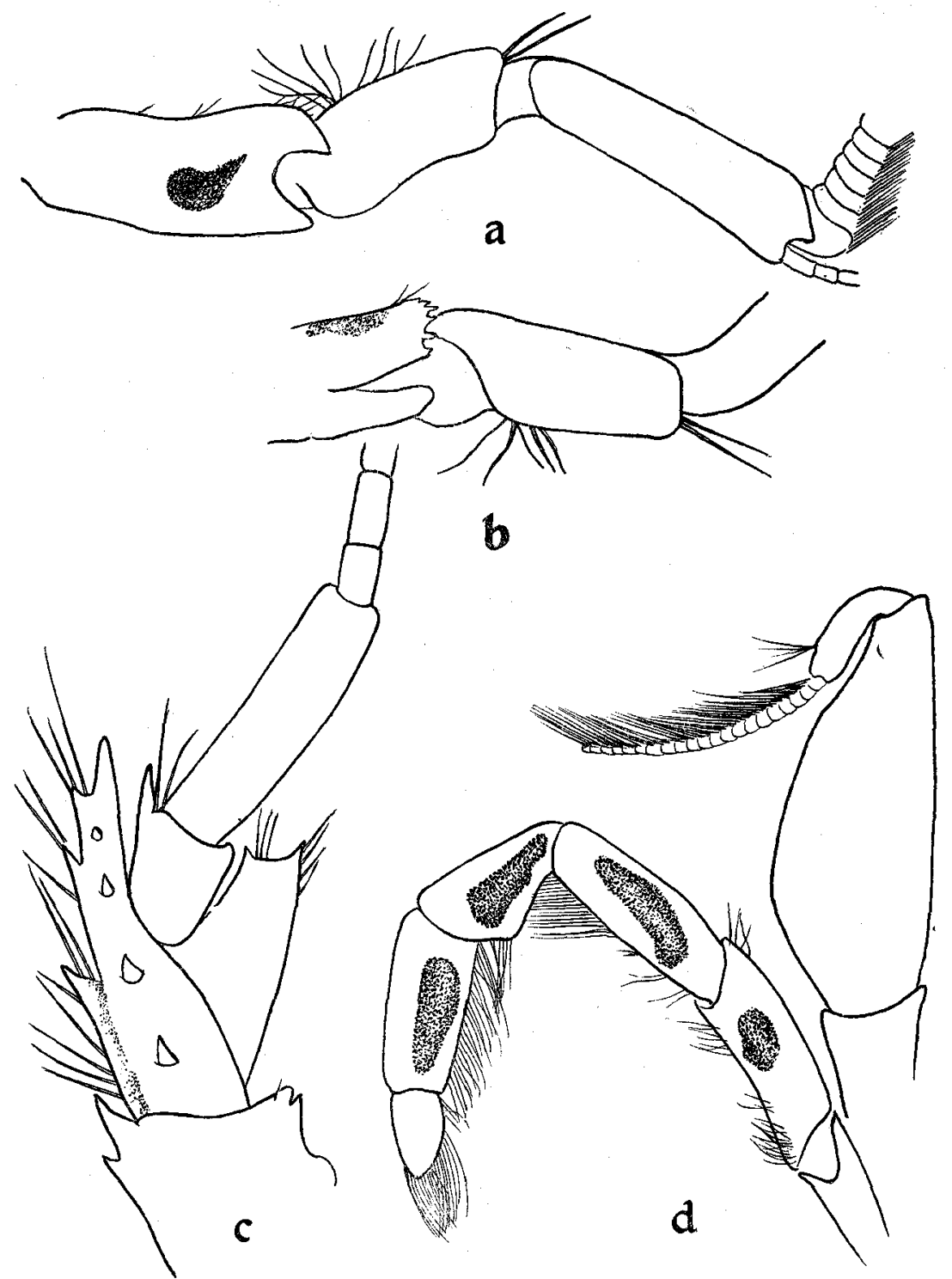

Fig. 5. Clibanarius eurysternus HILGENDORF.

a, Upper vitw of left antennule, $\times 33$. b, lateral view of the same, $\times 33$. c, upper view of left antenna, $\times 33$. d, upper view of left third maxilliped. $\times 33$.

Second and third legs rather compressed, ornamented with tufts of long hairs; carpus with a spine on distal border; dactylus distinctly longer than propodus, armed on inner margin with 10-12 spinules.

Colour in life. Ground colour of the carapace yellowish white. The anterior parts marked with four red-brown stripes longitudinally (after Tokioks's observation).

Colour in alcohol. Anterior parts of carapace, eye-stalk, peduncles of antennule 
and antenna, and third maxilliped marked with red-brown stripes as in the text-figures. Material examined.

Nakano-shima, 1 \% (TK. No. 567) (e), June 2-13, 1953 (ТокıокA).

Takara-jima, 1 ( (TK. No. 568) (a), 3 우 f (b, c, d), May 25-June 1, 1953 (ToKiokA). Dimensions (in $\mathrm{mm}$ ).

\begin{tabular}{|c|c|c|c|c|c|}
\hline & $\hat{\delta}(\mathbf{a})$ & P (b) & $q(\mathrm{c})$ & 우 (d) & ㅇ $(\mathrm{e})$ \\
\hline c. 1 . & 6.2 & 7.2 & 9.0 & 8.0 & 8.3 \\
\hline c. b. & 6.2 & 6.5 & 8.5 & 7.0 & 8.3 \\
\hline
\end{tabular}

Distribution. Tokara Islands: Nakano-shima (northern limit), Takara-jima; and Indo-West Pacific region. This species has not been described from Japanese waters.

7. Clibanarius corallinus (H. MILNE EDWARDS, 1848)

(Figs. 6-7)

New Jap. name: Minami-yokobasami

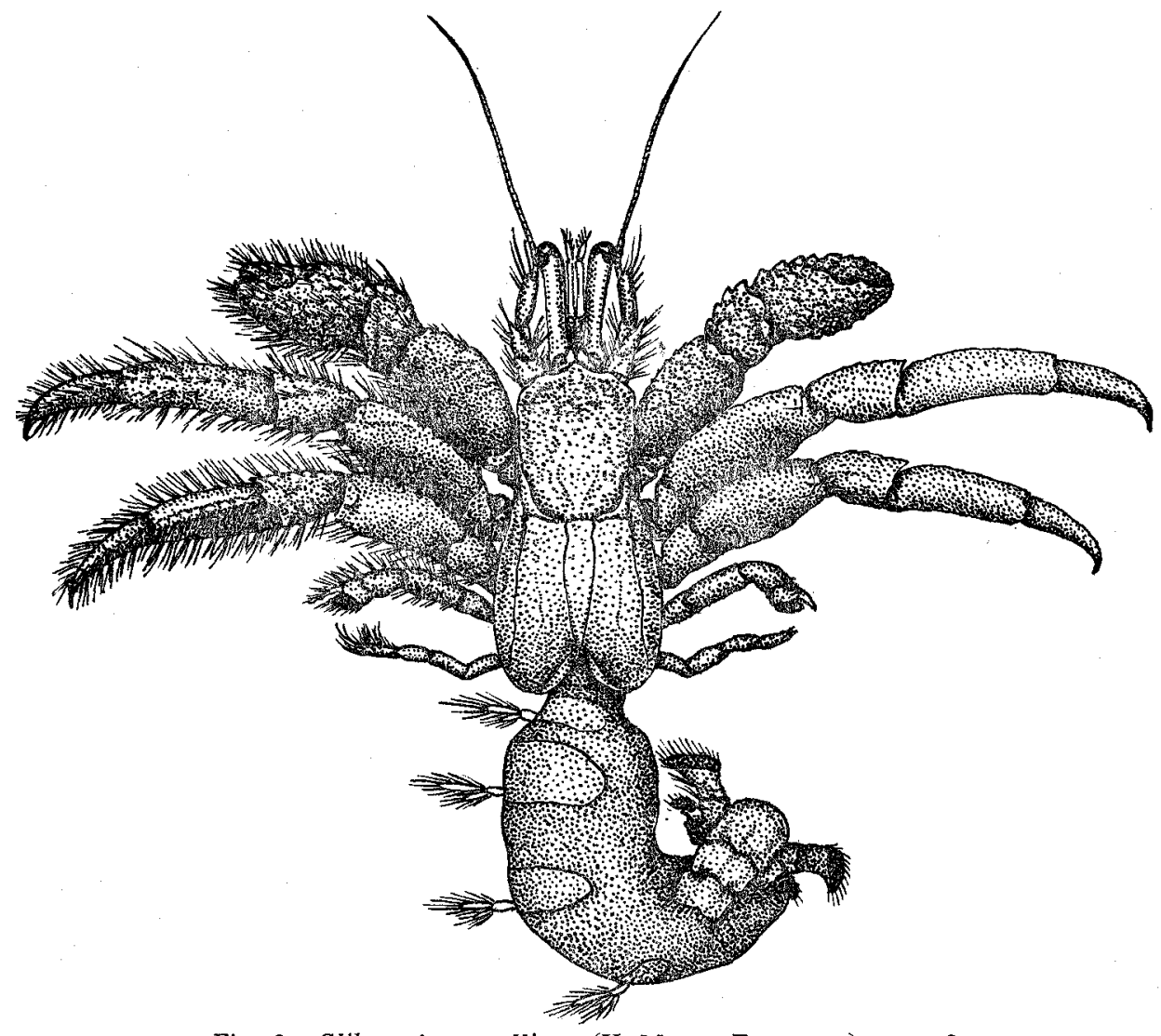

Fig. 6. Clibanarius corallinus (H. MILNE EDWARDS), $\times 2$. 
Pagurus corallinus H. Milne Edwards 1848, Ann. Sci. Nat., ser. 3, vol. 10, p. 63-New Guinea, type-locality (not seen).

Clibanarius corallinus Terao 1931, p. $360 ; 1914$, p. 181, fig.-Nakano-shima, Tokara Islands. Clibanarius globosimanus STIMPSON 1858, p. 85 ; 1907, p. 210-Loo Choo (Okinawa-Hontō).

Description. Carapace slightly convex in both directions, longer than broad, the proportion of length to breadth being $3: 2$; upper surface punctate especially in posterior part; its lateral margins ornamented with tufts of hairs.

Eye-stalk excluding eye as long as anterior border of carapace, and a little longer than fantennular peduncles. Basal peduncles of antennule slender, very long, the

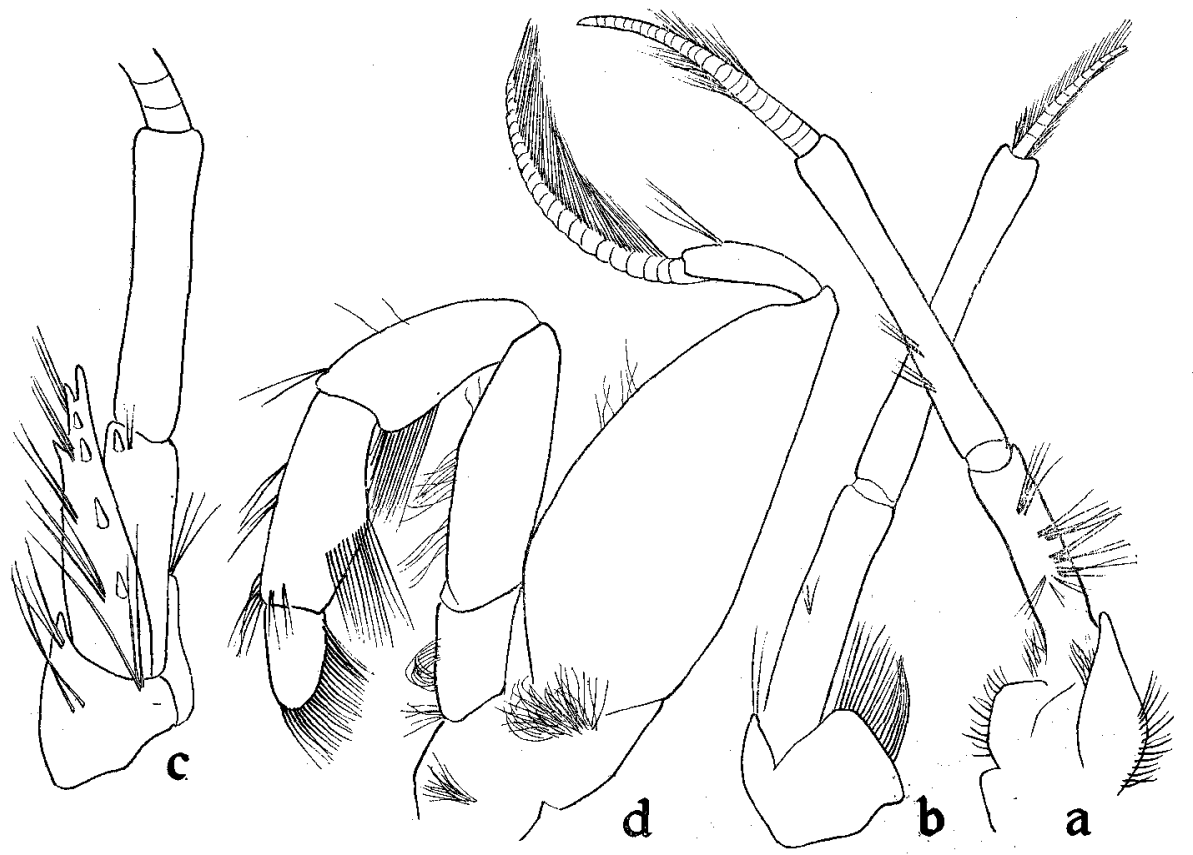

Fig. 7. Clibanarius corallinus (H. MILNE EDwards).

a, Upper view of left antennule, $\times 25$. b, lower view of the same, $\times 25$. c, upper view of left antennule, $\times 25$. d. lower view of left third maxilliped, $\times 12$.

proportion of the segments being $3: 4: 7$. Antennal acicle with six spinules, two of them on outer margin, four spinules on inner one, superpassing the proximal end of last joint of the antennal peduncles. The penultimate joint (basipodite) with a spinule on inner angle.

Chelipeds subequal; merus with two acute teeth at the distal end of outer lower margin and with minute, acute teeth or spinules on inner lower edge and upper distal margin. The upper surface of wrist, hand and fingers armed with thorn-like tubercles bordering tufts of setae.

Second and third pairs subcylindrical, smooth and sparsely setose; ischium and merus much compressed, ornamented on both upper and lower borders with tufts of 
setae; carpus with a spine at distal end of upper surface; propodus provided on the distal end of both inner and outer margins with a small spine; the outer surface of propodus of left leg of the third pair much flattened, bearing closely-set tufts of long setae; dactylus distinctly shorter than propodus. Fourth pair much compressed, ornamented on both upper and lower margins with tufts of hairs.

Colour in life. Body of a dark brown-purple colour. Eye-stalk marked with reddish brown lines.

Colour in alcohol. Carapace brownish purple in anterior half, while bluish white in posterior half. Eye-stalk whitish except reddish proximal part. Peduncles of antennule and antenna reddish brown. Merus and carpus of thoracic legs brownpurple; propodus and dactylus dark red.

Material examined.

Nakano-shima, 1 sิ, 1 우 (TK. No. 569), May 25, June 3-13, 1953 (TokIokA).

Takara-jima, 6 송 111 우 우 (TK. Nos. 570, 571), May 26-June 1, 1953 (TokiokA).

Dimensions (in $\mathrm{mm}$ ).

$\begin{array}{lcc} & \text { largest } \hat{~} & \text { largest 우 } \\ \text { c. } 1 . & 19.5 & 18.5 \\ \text { c. b. } & 12.0 & 12.0\end{array}$

Distribution. Mergui Archipelago, Bonin Islands, Formosa; Japan: AmamiOshima, Tanega-shima and above-mentioned localities. This species, according to Dr. $\mathrm{T}$. ToKIoKA, is found very commonly in Tokara Islands. Tanega-shima is the northern limit of this species.

\section{Clibanarius virescens (KRAUSS, 1843)}

(Figs. 8-9)

Jap. name: Iso-yokobasami

Pagurus virescens KRauss 1843, Die Südafrikanische Crustacea, p. 56, pl. 4, f. 3-Natal, typelocality (not seen).

Clibanarius virescens BUTTENDIJK 1937, p. 263-Australasiatic Seas.

Clibanarius bimaculatus ORTMANN 1892, p. 291-Tokyo Bay, Sagami Bay.

Clibanarius bimaculatus BALSS 1913, p. 41, f. 28-Satsuma, Southern Kyushu; Formosa.

Clibanarius bimaculatus TERAO 1913, p. 360 ; 1914, p. 109, f. -Satsuma.

Clibanarius bimaculatus MrYake 1949, p. 739, f. 2136-Japan.

Description. Carapace depressed; its greatest breadth equal to about two-thirds the length; the upper surface naked, glabrous, with tufts of bristles in posterior half.

Eye-stalk excluding eye a little longer than anterior border of carapace, but slightly shorter than antennular peduncles. Antennal acicle slender, setose, with two spinules only on inner margin, reaching beyond the proximal end of last joint of antennal peduncles.

Chelipeds almost equal in both sexes; arm provided with an acute tooth at distal end of upper margin; palm and fingers thickly beset with thorn-like tubercles on 


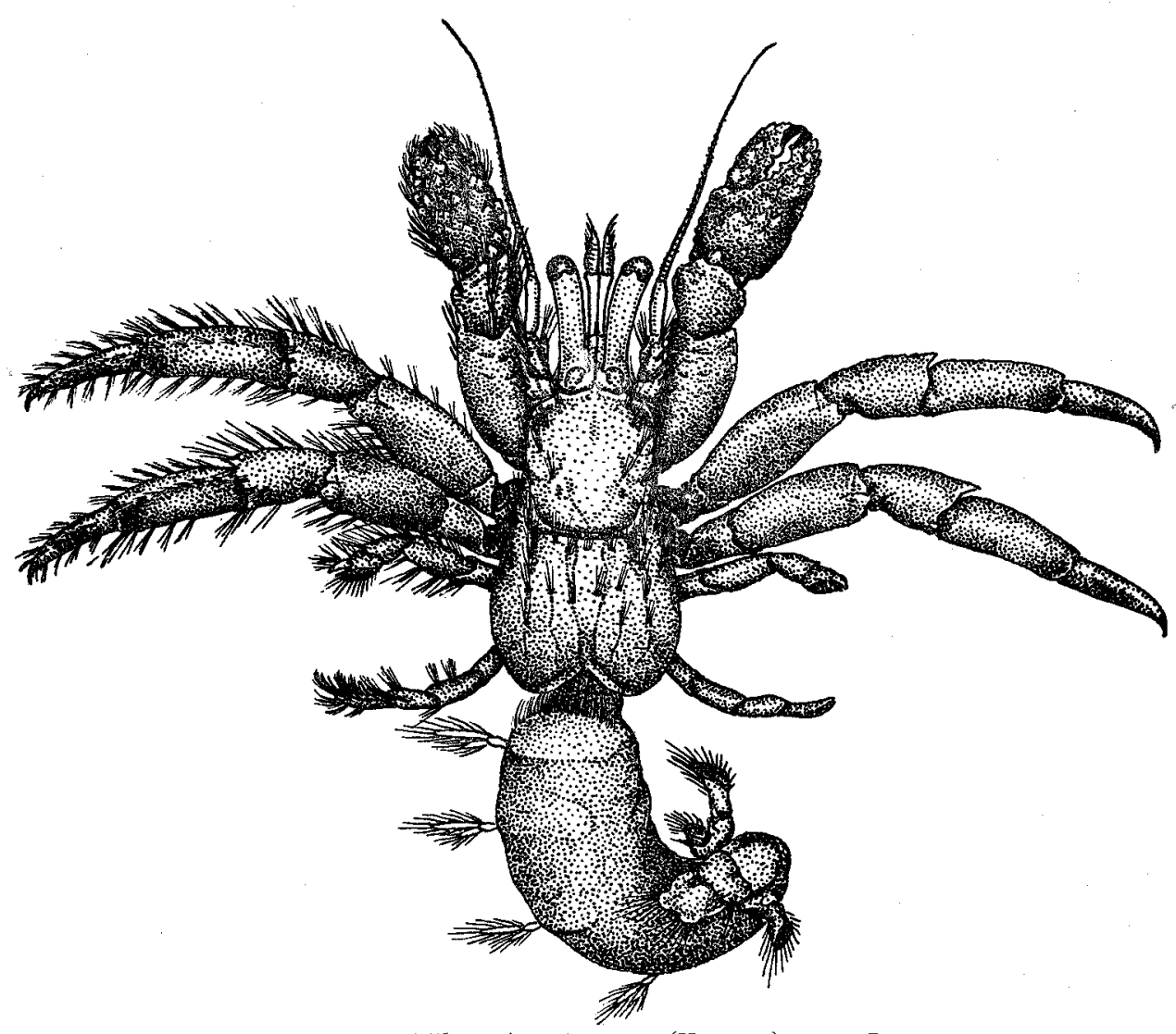

Fig. 8. Clibanarius virescens (KRAUSS), $\times 5$.

upper surfaces.

Second and third legs smooth, glabrous, furnished with tufts of setae and long hairs sparsely. There is a distinct ridge separating the upper and outer surface only in the left propodus of the third pair.

Remarks. Ortmann (1892, p. 291) and Balss (1913, p. 14) have described Clibanarius bimaculatus (DE HAAN) from Japan. BUITENDIJK (1937, p. 264), however, has identified them as C. virescens (KRAUSS) by the following characters after her revision of the material deposited in the Strassbourg Museum and in the collection in München. According to her description, they agree with each other and differ from DE HAAN's description in having spines on the palm of the chelipeds and a ridge separating the upper and outer surfaces of the propodus of the third leg. Already TERAO (1913) has stated that the materials from Kagoshima, Southern Kyushu, differ from DE HAAN's original description by having almost equal chelipeds.

Colour in life. Carapace bluish with numerous minute spots of a white colour in most parts, but brownish purple in anterior third. Eye-stalk, ophthalmic scale, antennule 


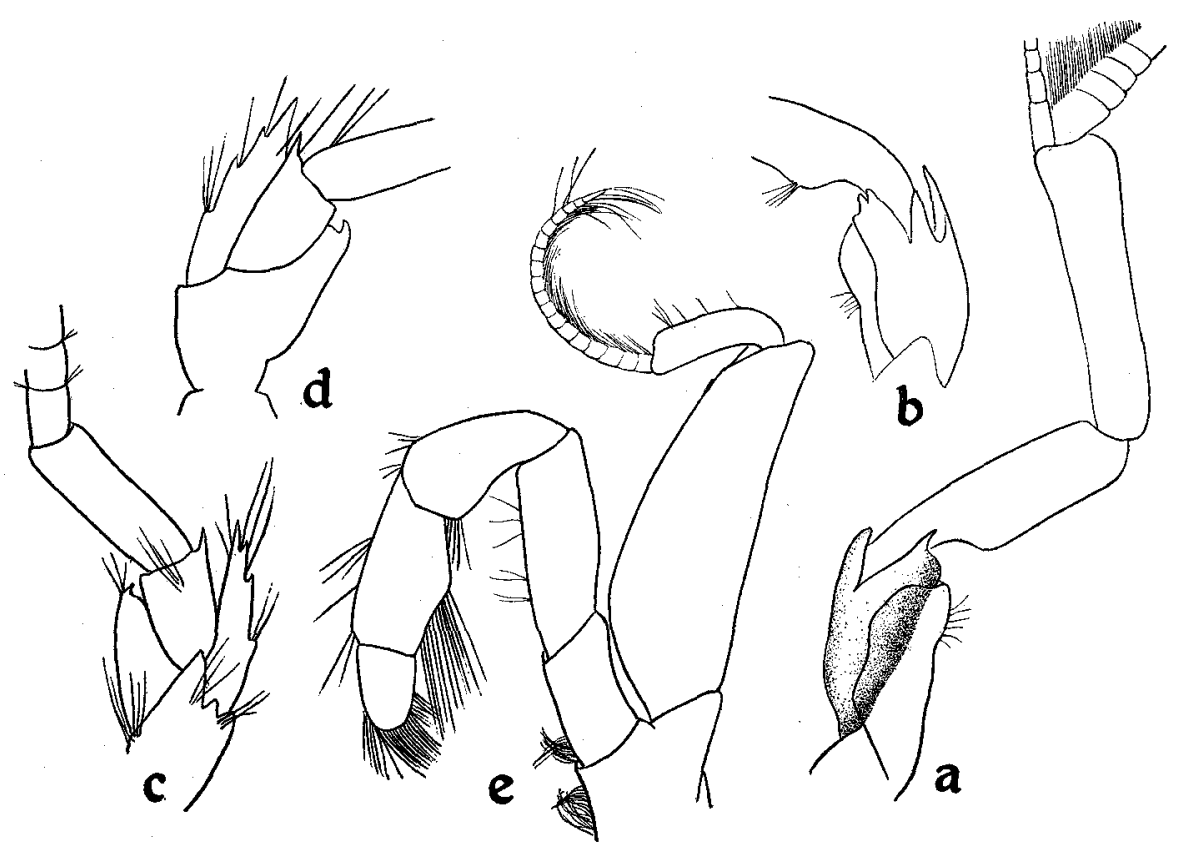

Fig. 9. Clibanarius virescens (KRAUSs).

a, Lower view of left antennule, $\times 40$. b, upper view of the same, $\times 40$. c, upper view of left antenna, $\times 40$. d, lower view of the same, $\times 40$. e, lower view of left third maxilliped, $\times 40$.

and antenna reddish brown. Cheliped reddish brown; fingers greenish gray; tips of fingers black. Second and third legs brownish purple, with two whitish cross-bands on distal and proximal ends of dactyli ; the proximal cross-band is somewhat brownish and broader than the distal one. The distal ends of propodi of second and third legs furnished with the same coloured cross-band as that in the proximal ends of dactyli. Fourth and fifth thoracic legs greenish gray. Abdomen whitish (after TokiokA's note).

Material examined.

Nakano-shima, $3 \hat{\delta}\}, 1$ ovig. ㅇ (TK. No. 572), May 25, June 3-13, 1953 (TokiokA).

Takara-jima, $4 \delta \delta, 3$ 우 우, 5 ovig. 우 우 (TK. No. 573), May 26-June 1, 1953 (TokiokA).

Dimensions (in $\mathrm{mm}$ )

Nakano-shima

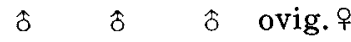
$\begin{array}{lllll}\text { c. } 1 . \quad 5.0 & 5.3 & 6.0 & 5.3\end{array}$
$\begin{array}{llll}\text { c. b. } \quad 3.0 & 3.5 & 3.8 & 3.3\end{array}$
Takara-jima

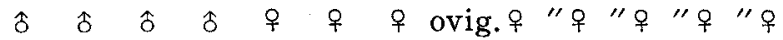
$\begin{array}{lllllllllllll}\text { c. } 1 . & 2.8 & 4.5 & 5.0 & 6.0 & 4.0 & 4.2 & 4.5 & 2.5 & 2.8 & 3.0 & 3.5 & 3.8\end{array}$
$\begin{array}{lllllllllllll}\text { c. b. } \quad 2.0 & 2.5 & 3,8 & 4.3 & 3.0 & 2.8 & 3.0 & 1.8 & 2.0 & 2.0 & 2.8 & 2.8\end{array}$ 
Since the smallest egg-laden female measures $2.5 \mathrm{~mm}$ in the length of carapace, this species from Tokara Islands seems to be a smaller member of the genus.

Distribution. From W. and S.E. Africa eastwards to Fiji Islands and as far as Japan. Its northern limit, according to the records, is Tokyo Bay.

\section{Clibanarius zebra rhabdodactylus FOREST, 1953}

(Figs. 10-11)

New Jap. name: Akatsume-yokobasami

Clibanarius zebra rhabdodatylus Forest 1953, p. 448, f. 3, 8-Hikueru I., Polynesia (type-locality).

Description. Carapace naked, punctate on upper surface ; rostrum small, triangular, being longer than the lateral angles.

Eye-stalk including eye rather stout and as long as antennular peduncle. Ophthalmic scale large, with three minute spinules near the apex. Antennal peduncle reaches the base of the eye; antennal acicle unarmed, rather small, slender from its base, being a little longer than the first joint of the peduncle. The third maxilliped with slender endopodite and broad exopodite; carpus and merus of the endopodite with soft, long hairs on inner margins, but without spines on both inner and outer margins.

Cheliped unequal ; right hand a little larger in the male; the upper surface with spiniform tubercles and tufts of setae. First and second ambulatory legs compressed, ornamented with hairs sparsely; merus very broad proximally and with hairs on both upper and lower margins; propodus twice as long as dactylus and with tufts of hairs on upper margin; dactylus with three spinules tufts of hairs on inner margin.

Colour in alcohol. Ground colour of the body light orange. Eye-stalk, carapace and legs marked with red-brown stripes. Eye-stalk with a broad, longitudinal stripe on dorsal surface. Carapace with four logitudinal bands on the surface; first and second ambulatory legs with five stripes, three of them on the outer surface of each segment. Ophthalmic scale and cheliped, however, of an uniform red-brown colour on dorsal surface.

It is easily distiguished by the following character. The typical species, Clibanarius zebra DANA has no stripe only in the dactyli of ambulatory legs.

\section{Material examined.}

Takara-jima, 2 s $\delta$ (TK. No. 574), May 26--June 1, 1953 (ToKıоKA).

Dimensions (in $\mathrm{mm}$ )

$\begin{array}{lll} & \text { 요 } & \text { के } \\ \text { c. } 1 . & 7 & 6 \\ \text { c. b. } & 4 & 4\end{array}$

Distribution. Polynesia, Indonesia and above-mentioned locality. This is the first record in Japanese fauna. 


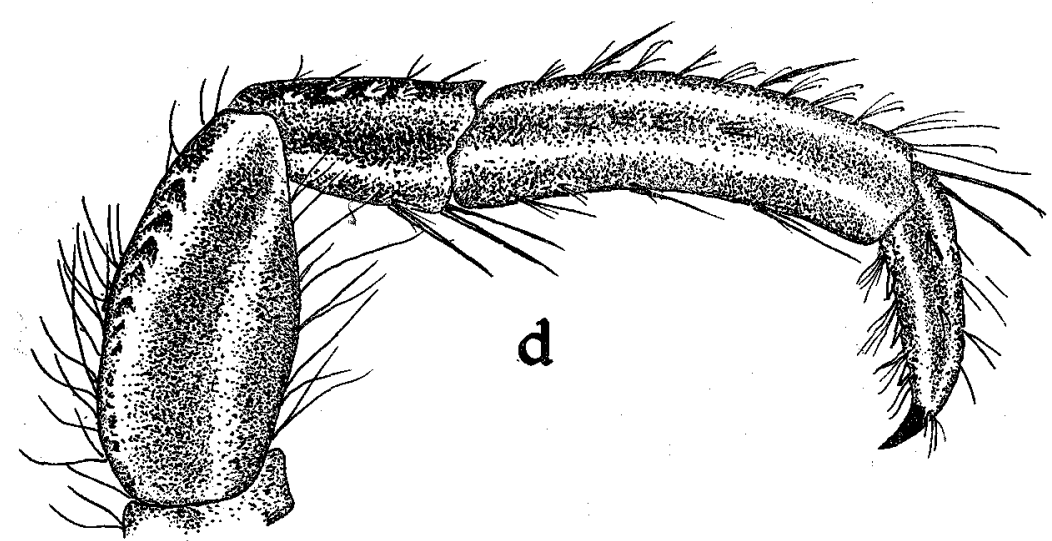

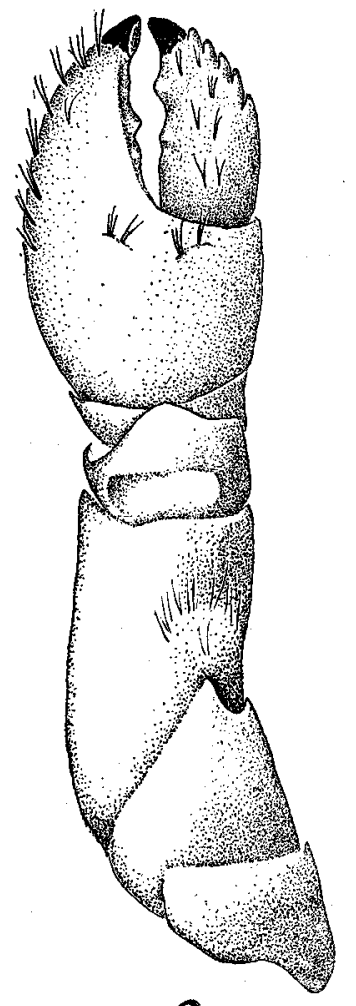

c

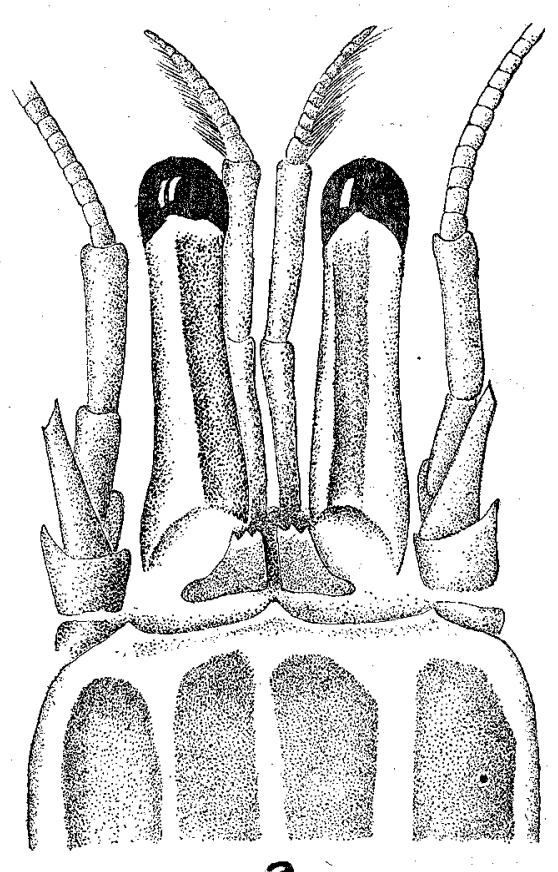

a

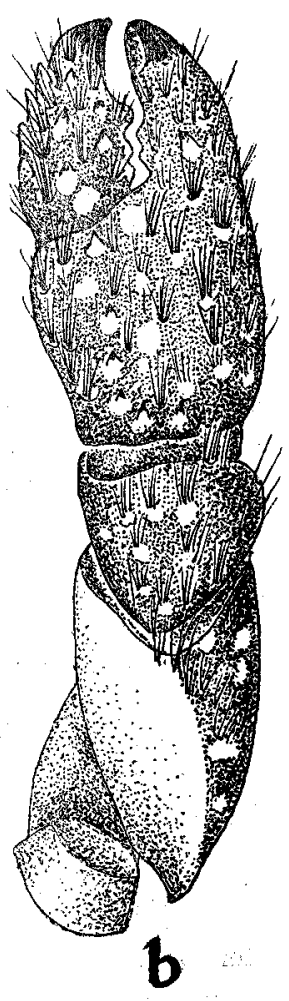

b

Fig. 10. Clibanarius zebra rhabdodactylus FOREST.

a, Frontal region, $\times 20$, b, upper view of right cheliped, $\times 13$. c, lower view of the same, $\times 13$. d, outer view of right second ambulatory leg, $\times 13$. 


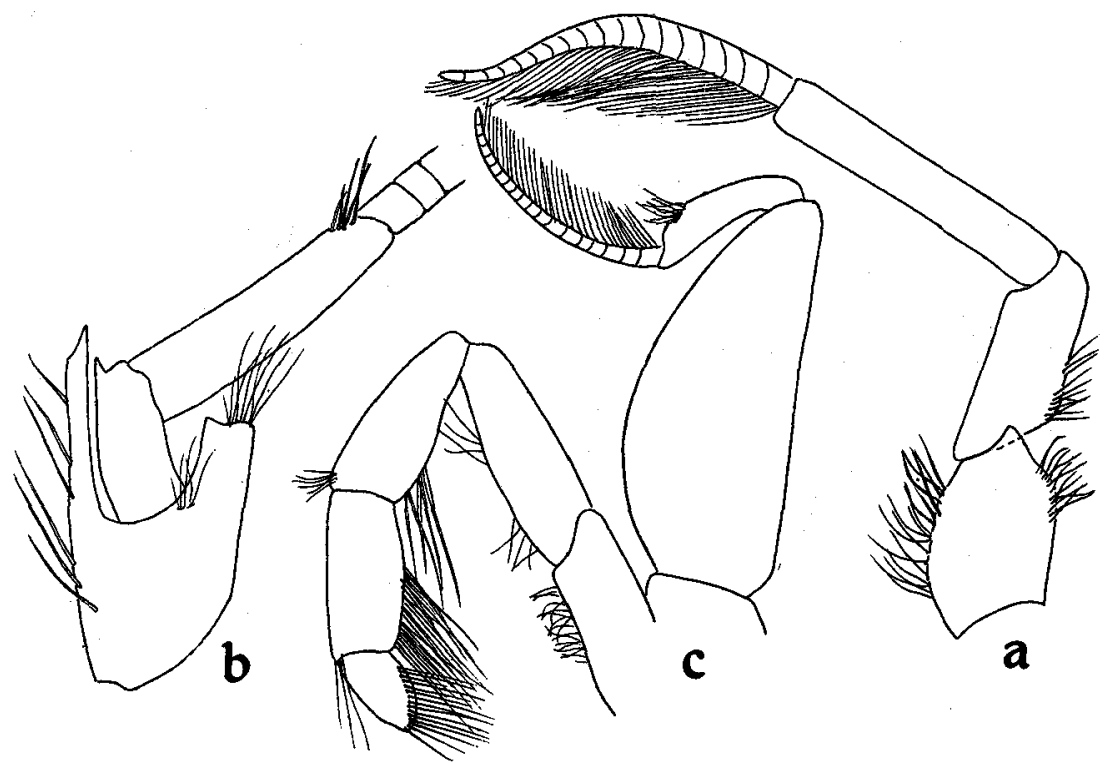

Fig. 11. Clibanarius zebra rhabdodactylus FOREST.

a, Lower view of left antennule, $\times 25$. b, lateral view of left antenna, $\times 25$. $c$, lower view of left third maxilliped, $\times 25$.

\section{Calcinus elegans (H. Milne EdWARDS, 1836)}

(Figs. 12-13)

New Jap. name: Wamon-sangoyadokari

Pagurus elegans H. MILNE Edwards 1836, p. 278, pl. 13, f. 2, 2a-Nouvelle-Irlande (Bismarck Islands, type-locality).

Calcinus elegans Stimpson 1858, p. 85-Ad insulam Loo Choo (Okinawa-Hontō).

Calcinus elegans TERAO 1913, p. 357-Miyano-ura, Tanega-shima.

Calcinus elegans NAKAZAwa 1927, p. 1041, f. 2004-South Sea.

Calcinus elegans Shinno 1933, p. 259-Seto, Prov. Kii (infested by a Bopyrid, Parapagurion calcinicola SHIINO).

Calcinus elegans MELIN 1939, p. 21-Bonin Islands.

Description. Carapace rather depressed, smooth, well calcified in anterior half, furnished on lateral margins and behind cervical groove with tufts of long, purplish hairs.

Eye-stalk excluding eye as long as anterior border of carapace, slightly longer than or almost equal to antennular peduncle, and much longer than antennal peduncle. Antennal acicle with six spinules, two of them on outer margin, four on inner one, reaching beyond the proximal end of the last joint of antennal peduncle. Ophthalmic scale triangular, with tip pointed.

Cheliped smooth, unequal; left one much larger; merus with three spines at distal end of outer lower margin in both chelipeds; carpus of left side provided on 

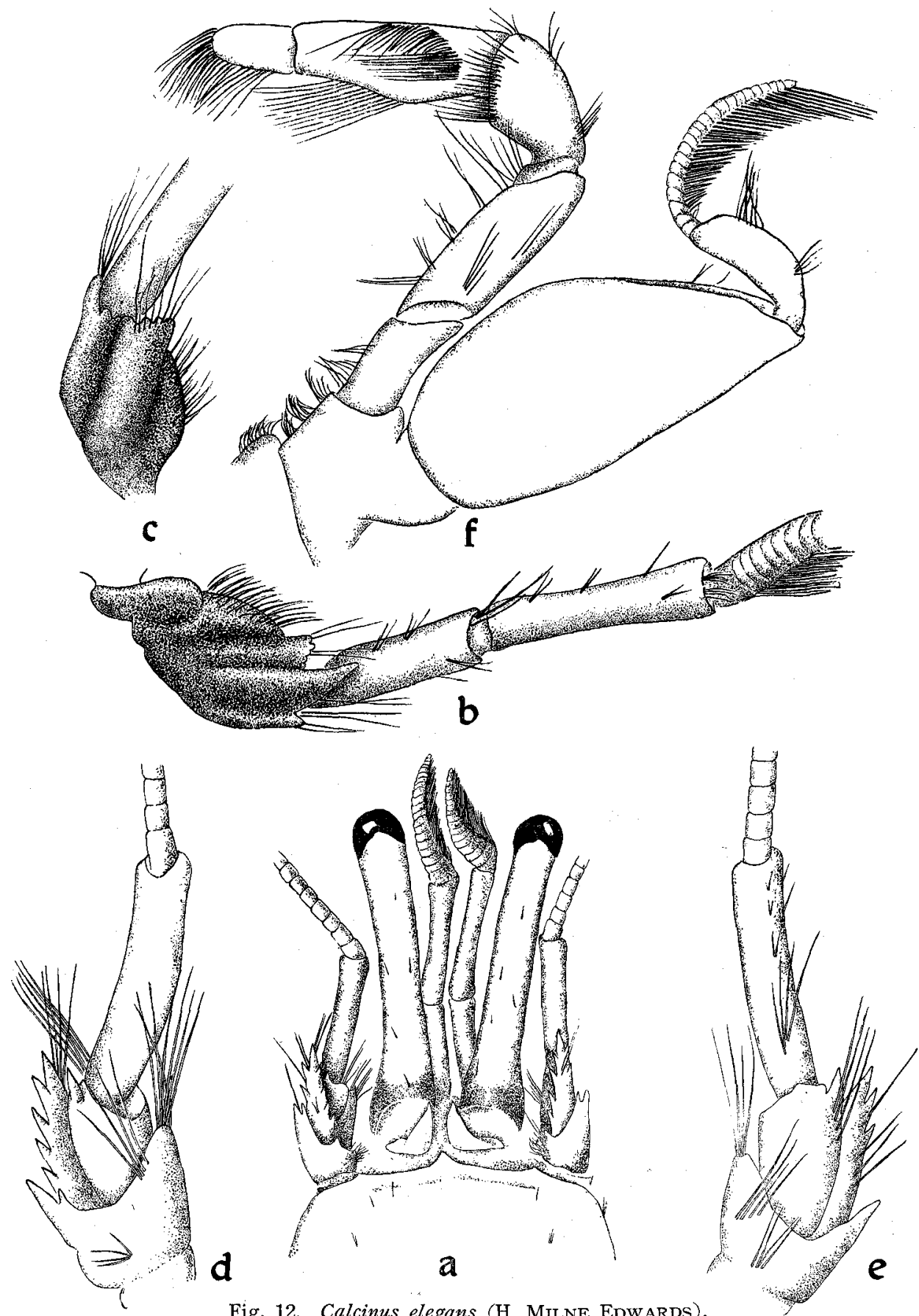

Fig. 12. Calcinus elegans (H. MILnE EDwarDS).

a, Frontal region, $\times 10$. b, upper view of left antennule, $\times 33$. c, lower view of coxopodite of the same, $\times 33$. d, lower view of the basal peduncle of left antenna, $\times 33$. e, upper view of the same, $\times 33$. f, lateral view of left third maxilliped, $\times 16$. 
upper surface with an oblique groove; palm stout, smooth, unarmed; dactylus and immovable finger as long as palm, covered with white, pearl-like granules on the surface, furnished on inner margin with tufts of short hairs; dactylus with three teeth on cutting margin. There is a gap between fingers. Right cheliped much com-
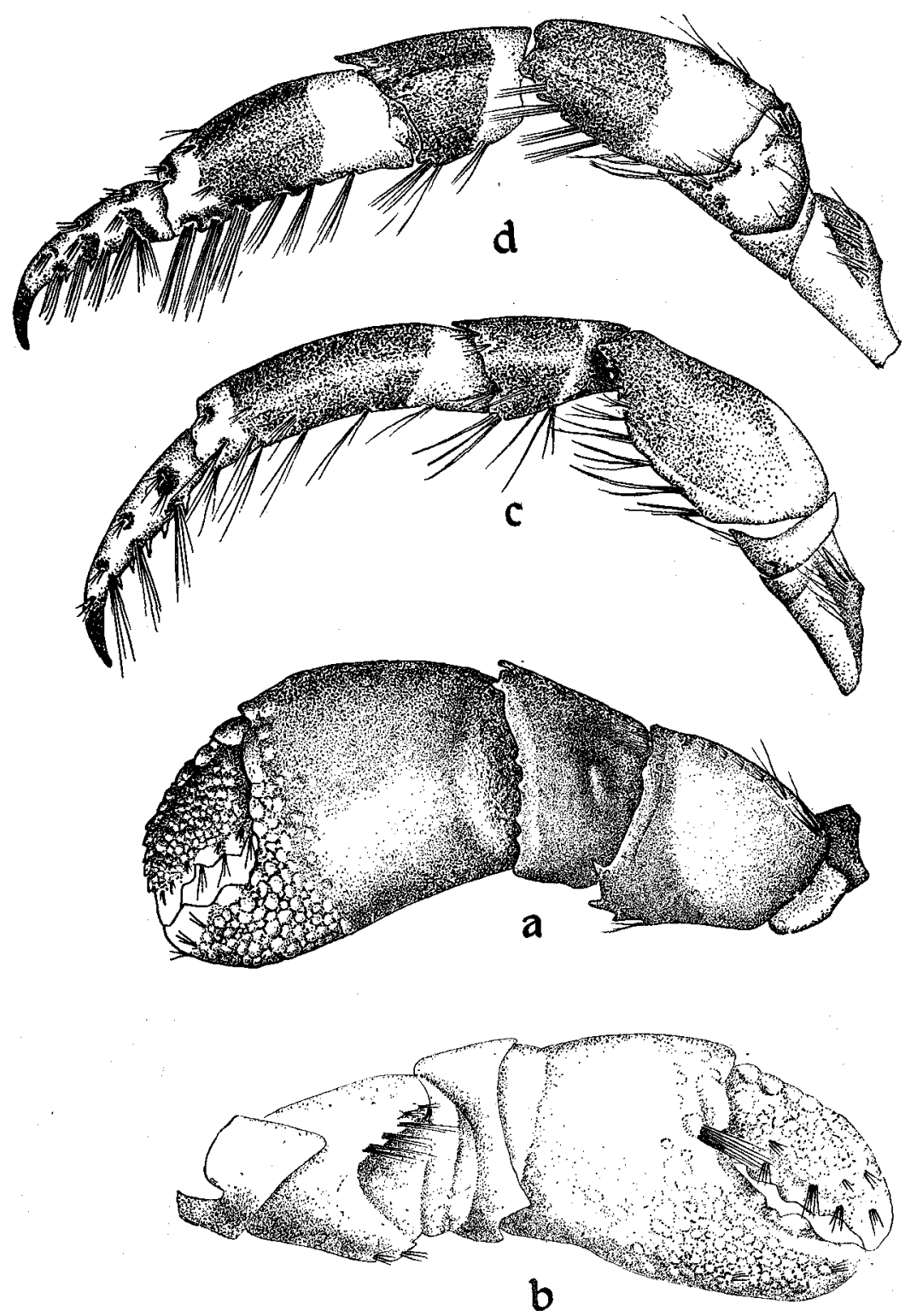

Fig. 13. Calcinus elegans (H. Milne Edwards).

a, Upper view of left cheliped, $\times 10$. b, lower view of the same, $\times 10$. c, upper view of left second leg, $\times 4$. d, upper view of left third leg, $\times 4$. 
pressed, its upper border acuminate; carpus with an acuminate tooth at distal end of upper margin; palm and immovable finger also with acute teeth on upper margin; fingers covered with the similar granules, but they are fewer as in left cheliped, tips of which pointed. Second and third legs smooth, almost equal to the larger cheliped, furnished on posterior margin with tufts of purplish hairs, especially dactylus and distal half of propodus of the third legs furnished with closely-set long setae.

Colour in life. Carapace white. Eye-stalk pale blue. Ophthalmic scale and proximal end of eye-stalk reddish. Antennule and antenna orange-yellow. Cheliped dark brown excepting fingers with white pearl-like tubercles. Second and third legs marked with alternate broad and narrow cross-bands; the narrow one blue. Dactylus blue with blackish purple spots. Hairs claret (after TokiokA's observation).

Colour in alcohol. Carapace yellowish. Eye-stalk light red. Base of eye-stalk and ophthalmic scale reddish yellow. Antennule and antenna orange. Cheliped yellowish brown with white tubercles. Second and third legs with dark red, broad cross-bands and whitish narrow bands. Dactylus whitish with the similar dark red spots. Hairs purple.

Material examined.

Nakano-shima, 1 ovig. ㅇ (TK. No. 575), June 2-13, 1953 (ТокіокA).

Takara-jima, 14 항, 6 우 우, 1 ovig. 우 (TK. No. 576), May 26-June 1, 1953 (ToKIoKA).

Dimensions (in $\mathrm{mm}$ ).

largest $\hat{\phi}$ largest 우 ovig. 우 ovig. 우

$\begin{array}{llll}\text { c. } 1 . \quad 13.0 & 10.0 & 6.5 & 8.7\end{array}$

$\begin{array}{llll}\text { c. b. } \quad 10.0 & 7.3 & 4.0 & 6.5\end{array}$

Distribution. Widely distributed in the Indo-Pacific region.

\section{Calcinus laevimanus (RANDALL, 1839)}

(Figs. 14-15)

Jap. name: Subesube-sangoyadokari

Calcinus tibicen Stimpson 1858, p. 85-Amami-Oshima; Loo Choo (Okinawa-Hontō), Bonin Islands.

Calcinus herbsti ORTMANN 1892, p. 292-Amami-Oshima.

Calcinus tibicen STIMPSON 1907, p. 208-No new locality.

Calcinus laevimanus Terao 1913a, p. 358-Naze, Amami-Oshima ; Naha, Okinawa-Hontō ; Koshun, Formosa.

Calcinus laevimanus TERAO 1913b, p. 591, f. 3, 3a-above-mentioned localities.

Calcinus herbsti NAKAzAWA 1927, p. 1040, f. 2003-Ryukyu; South Sea.

Calcinus herbstii SHIINo 1933, p. 263-Seto, Prov. Kii (infested by a Bopyrid, Propseudione rhombicosoma SHIINO).

Calcinus laevimanus NAKAZAWA 1949, p. 739, f. 2138-Amami-Oshima, Ryukyu, Formosa, Bonin Islands, South Sea.

Description. Carapace smooth, somewhat punctate; its greatest breadth longer than two-thirds of the length. Eye-stalk excluding eye a little shorter than anterior 
borber of the carapace, almost equal to antennular peduncle, and longer than antennal peduncle. Ophthalmic scale triangular with tip acuminate. Antennal acicle with a spinule on outer margin, reaching the distal end of penultimate joint of the antennal peduncle.

Cheliped smooth, unequal; the left cheliped much more massive than the right one; wrist of the left cheliped with an oblique groove on upper surface; palm very large, nearly as long as broad, and a little longer than movable finger of a female from Nakano-shima; immovable finger with an obtuse tooth; there is no gap between

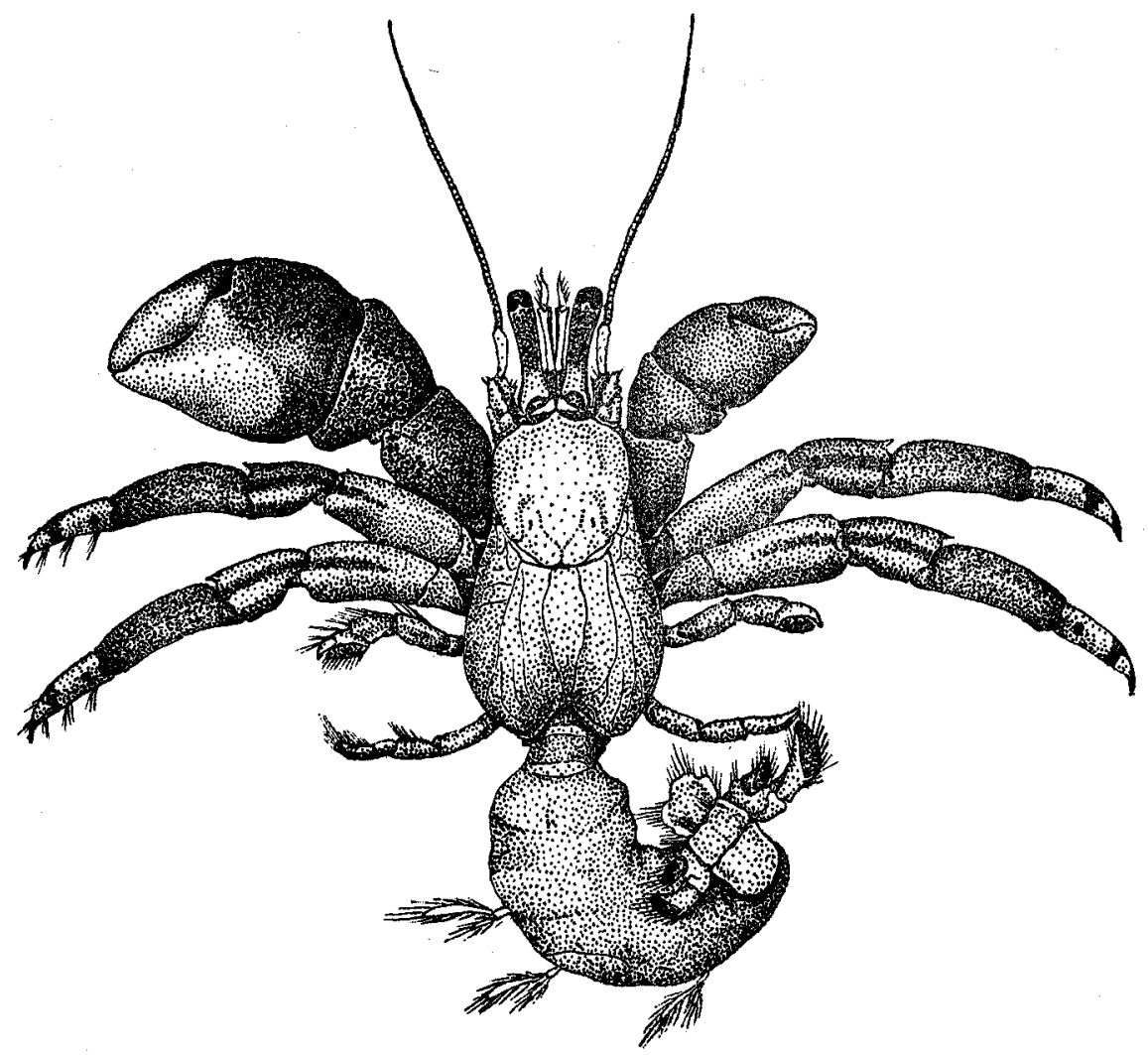

Fig. 14. Calcinus laevimanus (RANDALL), $\times 4$.

fingers; the cutting margins of them with tufts of setae. The right cheliped much compressed ; fingers more or less rugose, hairy on the surface with tips spoon-shaped.

Second and third legs shorter than the larger cheliped; smooth and unarmed, but only in carpus there is a spine at distal end of upper margin; dactylus and distal part of propodus with a few tufts of setae; dactylus much shorter than propodus.

Colour in life. Carapace pale blue; the proximal third of eye-stalk blue, but the distal two-thirds of an orange colour; antennule and antenna also orange. Cheliped blackish purple, except white distal parts. Dactylus and posterior half of 


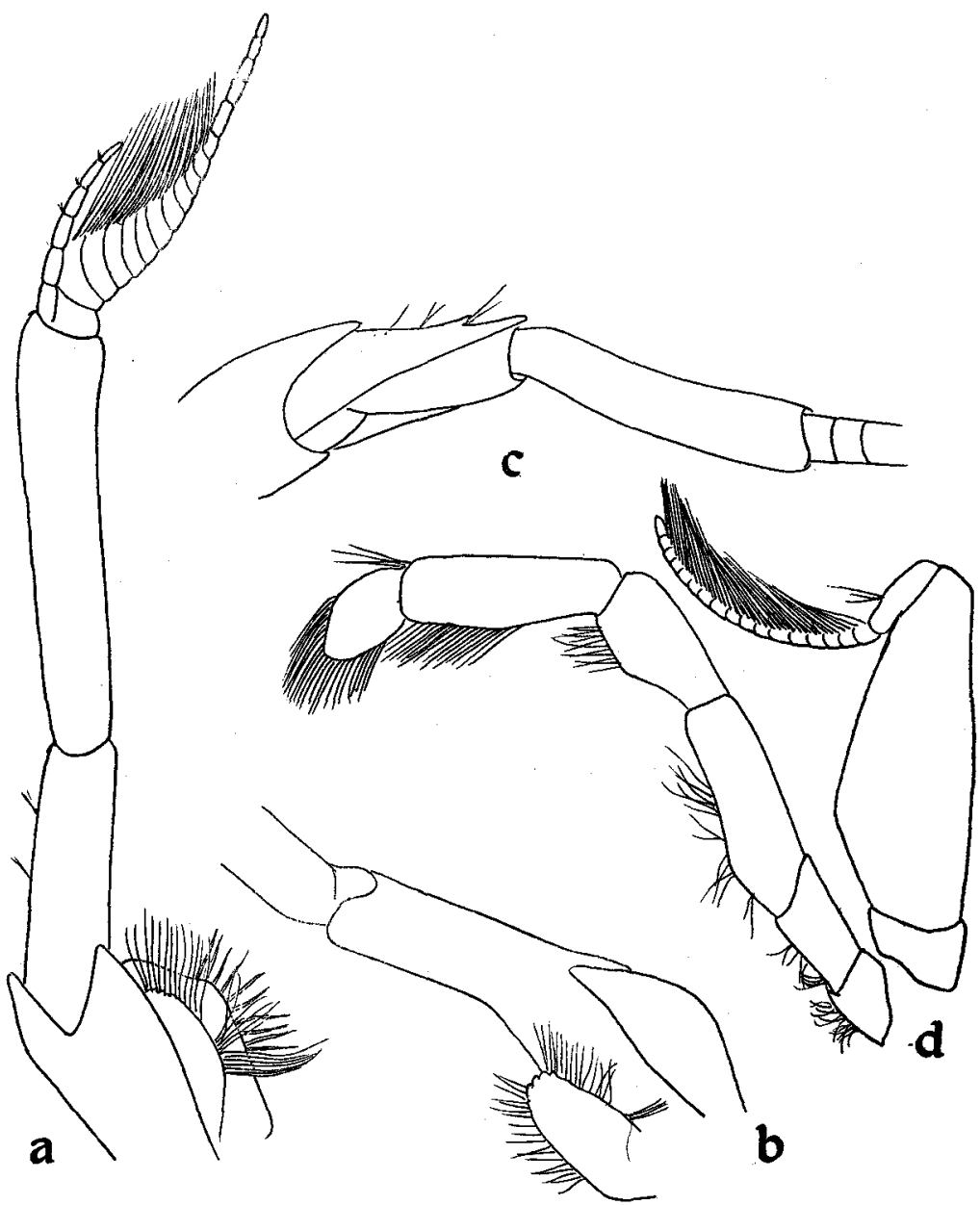

Fig. 15. Calcinus laevimanus (RANDALL).

a, Lateral view of left antennule, $\times 33$. b, lower view of basal joints of the same, $\times 33$. $c$, lateral view of basal joints of left antenna, $\times 33$. $d$, lower view of left third maxilliped, $\times 16$.

propodus of outer surface of the left cheliped of a white colour. Fingers of right cheliped reddish at the base and the tip white; merus and carpus of second and third legs yellowish brown and two dark brown lines on outer surface; propodus orange; dactylus white and marked with a yellowish brown spot on both inner and outer sides, besides them there is a cross-band of the same colour near the distal end of claw where it is black.

Colour in alcohol. Body whitish. The distal two-thirds of eye-stalk of an orange colour, but the proximal third pale red. Antennule and antenna yellowish. Chelipeds bluish brown, except white distal parts. Second and third legs light reddish brown with red long lines. 
Material examined.

Nakano-shima, 1 ㅇ (TK. No. 577), May 25, June 3-13, 1953 (TokiokA).

Takara-jima, 4 항, 7 우 우, 1 ovig. 우 (TK. No. 578), May 26-June 1, 1953 (TokiokA).

Dimensions (in $\mathrm{mm}$ ).

\begin{tabular}{lrrr} 
& \multicolumn{1}{c}{$\hat{\mathrm{o}}$} & \multicolumn{1}{c}{ q } & ovig. + \\
c. 1. & 5.8 & 10.0 & 9.0 \\
c. b. & 4.0 & 7.5 & 7.5
\end{tabular}

Distribution. Indo-Pacific region from S. E. Africa to Hawaii. The northern-most locality is Seto, Prov. Kii, Japan.

\section{Calcinus gaimardi (H. MilNe EdWARDS, 1848)}

(Figs. 16-17)

Jap. name: Kuriiro-sangoyadokari

Pagurus gaimardi H. MILNE EDWARDS, p. 63-Amboina, type locality (not seen).

Calcinus gaimardi ORTMANN 1892, p. 294-Amami-Oshima.

Description. Carapace smooth, polished, well calcified. Eye-stalk much longer than anterior border of carapace, and also longer than peduncle of antennule and

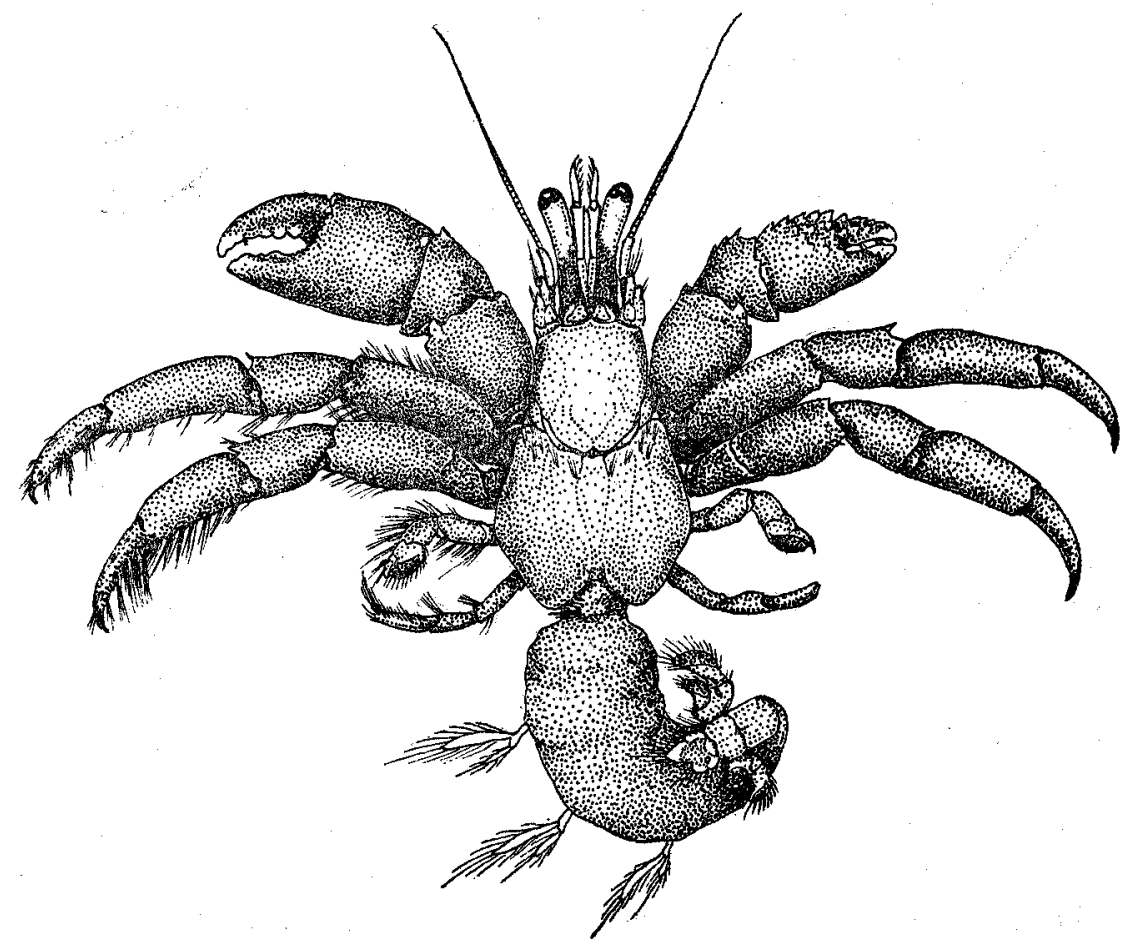

Fig. 16. Calcinus gaimardi (H. MrLnE EdwaRDS), $\times 2.5$. 

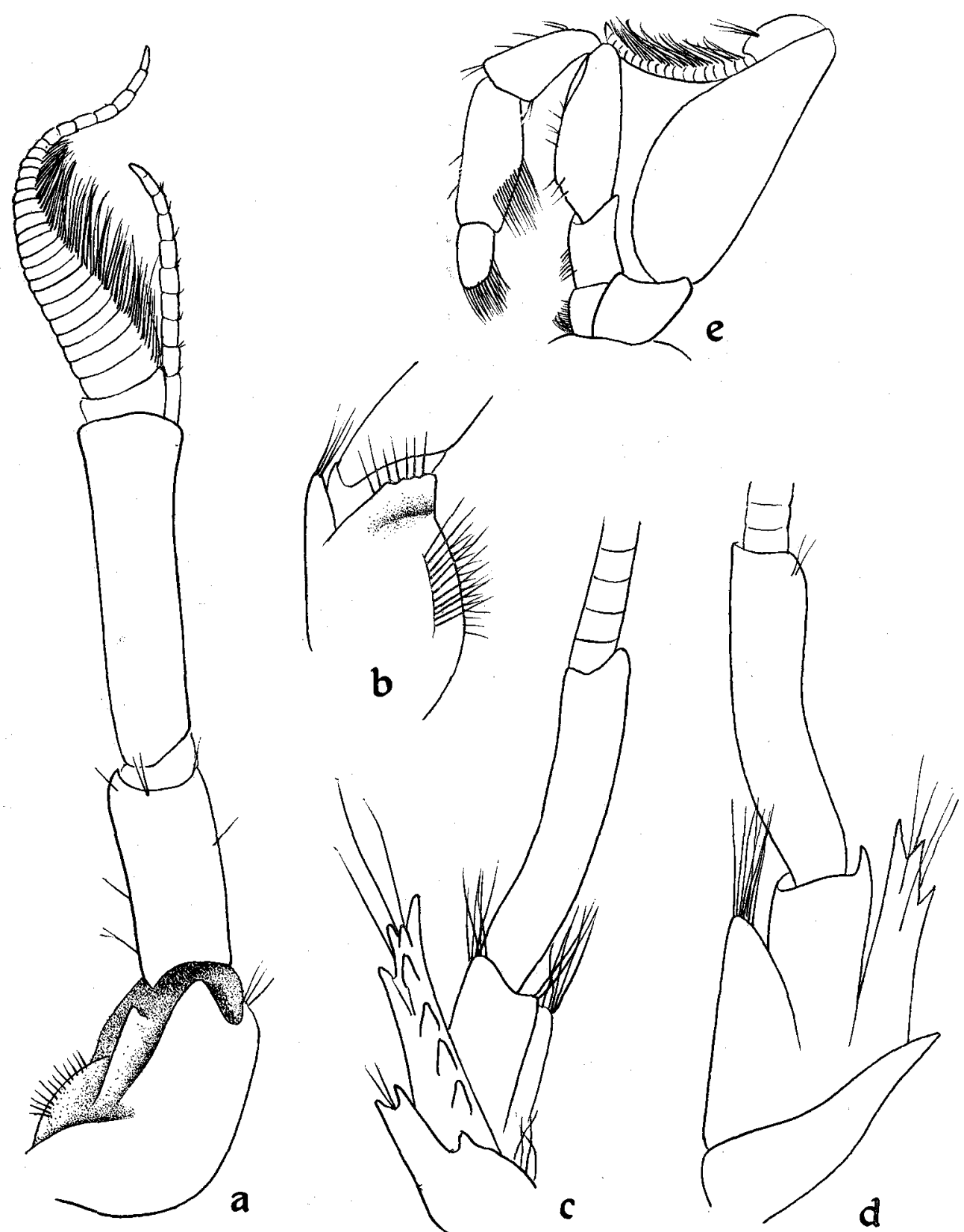

a

Fig. 17. Calcinus gaimardi (H. MILNE EDWARDS).

a, Lateral view of left antennule, $\times 33$. b, lower view of coxopodite of the same, $\times 33$. c, upper view of basal peduncles of left antenna, $\times 33$. d, lateral view of the same, $\times 33$. e, lower view of left third maxilliped, $\times 16$. 
antenna. Antennal acicle with five spinules on inner margin, but two on outer one, overreaching one-fourth of the distal end of penultimate joint of the antennal peduncle. Coxopodite of antenna with two spinules on outer distal angle, and with a spiniform tubercle on inner distal one.

Chelipeds smooth, hairless; the left cheliped larger than the right one. There is an oblique groove on upper surface of wrist; palm longer than dactylus; immovable finger with two obtuse teeth, movable finger with four ones on cutting margins; fingers with a few tufts of setae on inner margin, tips of which spoon-shaped; there is a large gap between them. Upper border of right cheliped angular, more or less hairy, serrated; merus with a spine at distal end of outer lower margin; wrist with a spine at the end of upper margin; propodus serrated on upper border in whole length; fingers somewhat rugose on anterior surface with tips spoon-shaped.

Second and third legs longer than the larger cheliped, the right one distinctly longer than the left; merus with a spinule at distal edge on outer lower margin; carpus with a spine at distal end of upper border; dactylus and propodus with tufts of hairs on posterior margin, especially third leg clothed thickly with above-mentioned hairs.

Colour in life. Carapace pale bluish; eye-stalk blue in distal half, while black in proximal half; antennule and antenna yellowish orange. Cheliped brownish purple with tips white; second and third legs red-brown with dark coloured spots in dactylus; its distal part whitish; claw black.

Colour in alcohol. Carapace white; antennule and antenna yellowish orange; eye-stalk pale red in anterior half, but brown-red in posterior half. Chelipeds dark brown-red with tips white: merus and wrist of second and third legs reddish-brown; propodus and dactylus light brown-red with red spots only in dactylus; hairs of propodus and dactylus a pale purple colour.

Material examined.

Takara-jima, $6 \hat{\delta}$ s, 2 ㅇ (TK. No. 579), May 26-June 1, 1953 (TokıokA).

Dimensions (in $\mathrm{mm}$ ).

\begin{tabular}{|c|c|c|c|c|c|c|c|c|}
\hline & $\hat{\delta}$ & $\hat{\delta}$ & $\hat{\sigma}$ & $\hat{o}$ & $\hat{\delta}$ & $\delta$ & 우 & 9 \\
\hline 1 & 4.0 & 6.0 & 6.5 & 8.0 & 10.0 & 10.5 & 4.5 & 10.8 \\
\hline & 3.1 & 4.5 & 4.5 & 53 & 7.0 & 73 & 36 & \\
\hline
\end{tabular}

Distribution. Indo-Pacific area. The northern limit of this species is Seto, Prov. Kii, Japan.

\section{Calcinus terrae-reginae HASWELL, 1882}

(Figs. 18-19)

New Jap. name: Aomidori-sangoyadokari

Calcinus terrae-reginae HASWELL 1882, p. 158-Claremont Islands, Queensland Coast (typelocality). 
Calcinus terrae-reginae DE MAN 1887, p. 439-Java.

Calcinus terrae-reginae DE MAN 1885, p. 226-Mergui Islands.

Calcinus latens terrae-reginae ALCOCK 1905, p. 57, pl. 5, f. 7-Maldives, Minikoy.

Calcinus terrae-reginae Estampador 1937, p. 505-Mindoro, Philippines.

Calcinus latens var. terrae-reginae BUITENDIJ K 1937, p. 269-Celebes, Kleine Soenda, Molukkas.

Description. Eye-stalk excluding eye exactly as long as anterior border of carapace; nearly equal to antennular peduncle of males, but a little shorter than that of females. Antennal acicle with five spinules, two of them on outer margin, the other three on inner margin, reaching beyond the proximal end of last joint of

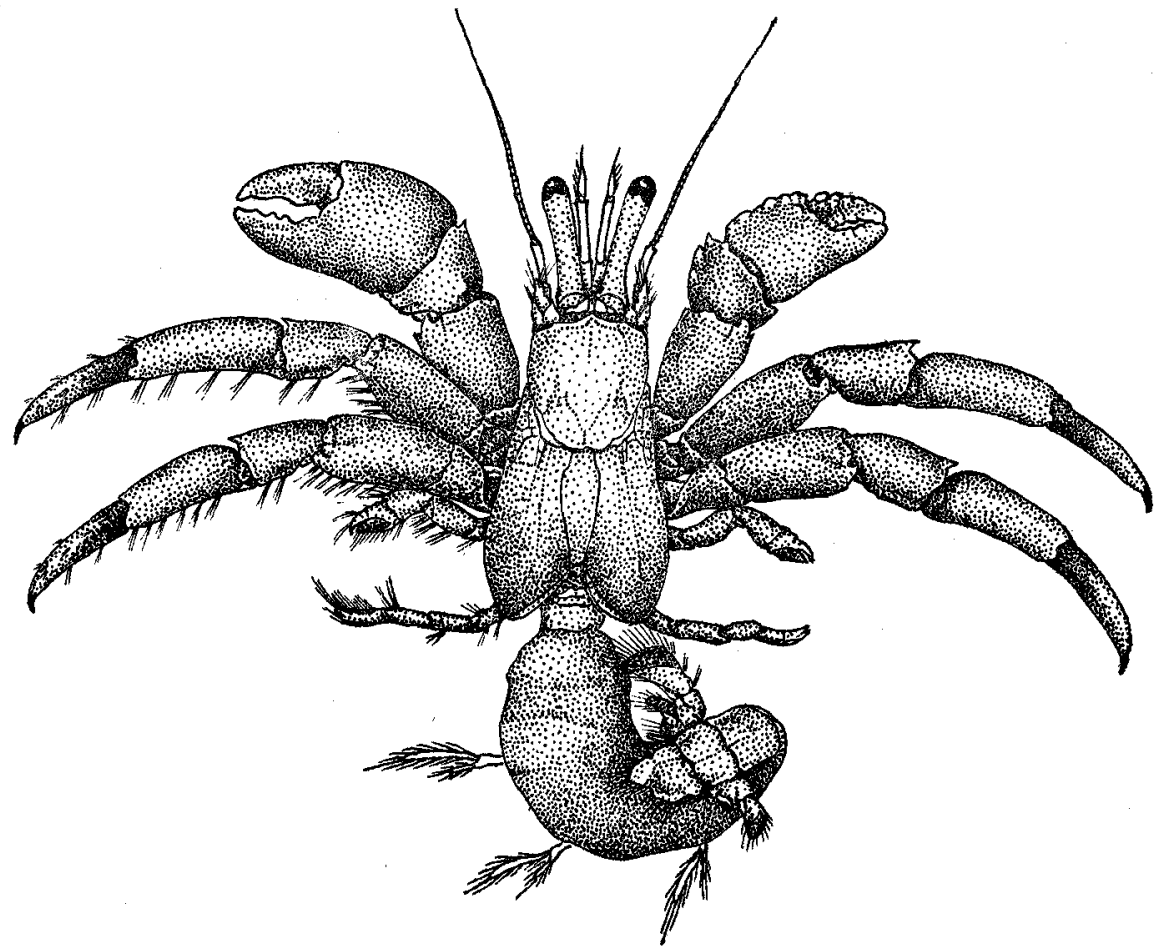

Fig. 18. Calcinus terrae-reginae HASWELI, $\times 3.5$.

antennal peduncle. Ophthalmic scale overreaches the base of eye-stalk, and the tip pointed.

Cheliped smooth, the left one longer than the right. The left cheliped a little longer than ambulatory legs; wrist with an oblique groove on upper surface, which is not so deep in the allied species $C$. latens; the under surface of palm smooth, but outer surface of palm and fingers covered with granules. The right cheliped much compressed; upper border of wrist, palm and immovable finger rested by laminate teeth.

Second and third legs strongly compressed; carpus with a spine at distal end of 
upper border; propodus and dactylus with tufts of bristles; the ornamentation of bristle of this species is more thickly than that of the species C. latens.

Colour in life. Carapace whitish, sometimes dark bluish gray; eye-stalk marked with blue in distal half, but orange in basal half; antennule and antenna orangebrown. Cheliped and legs grayish blue and olive; dactylus of second and third legs

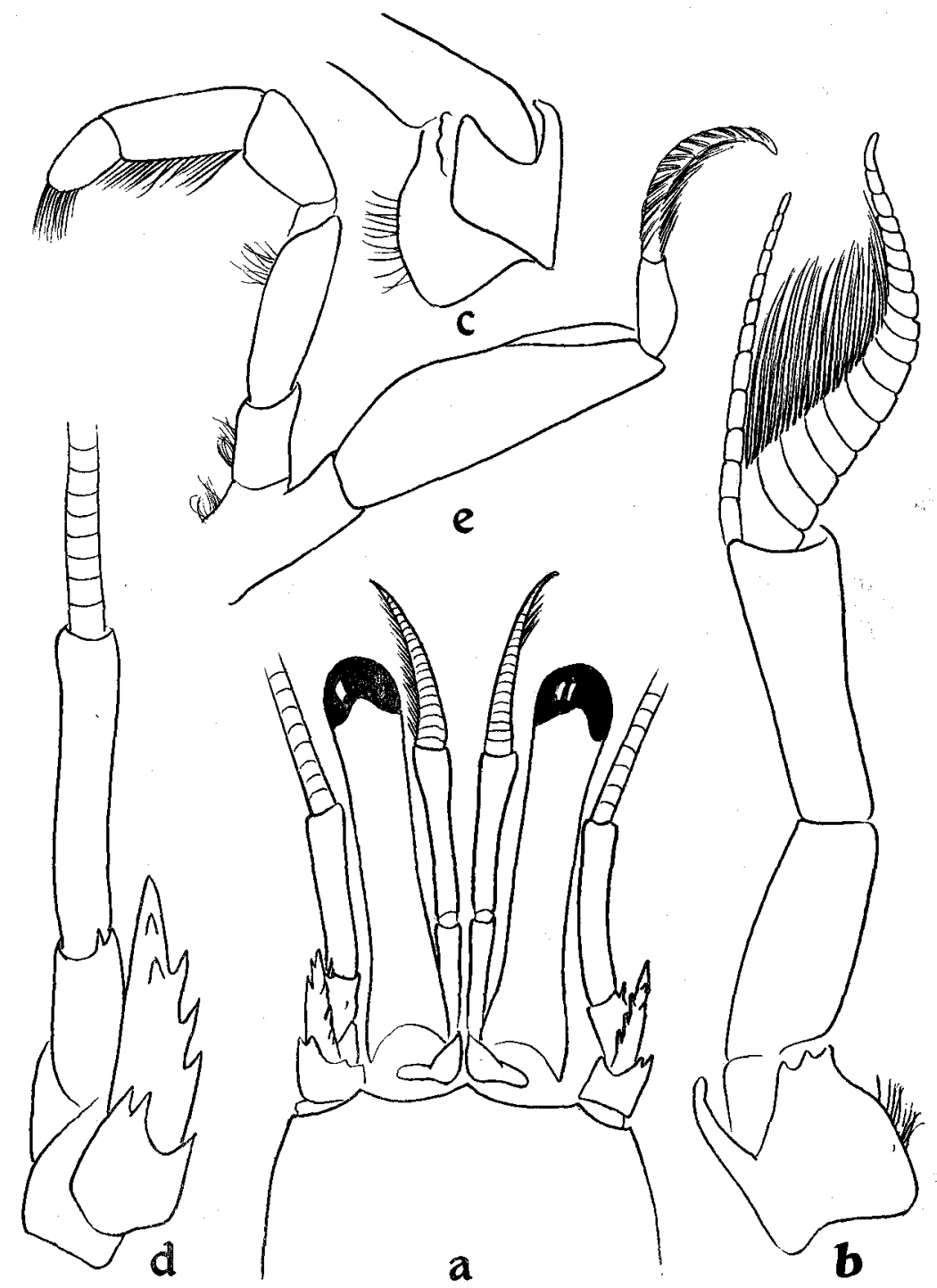

Fig. 19. Calcinus terrae-reginae HASWELL.

a, Frontal region, $\times 16$. b, lateral view of antennule, $\times 50$. c, lower view of coxopodite of the same, $\times 50$. d, upper view of antenna, $\times 50$. e, lower view of left third maxilliped, $\times 33$. 
with a purplish brown cross-band at the base; propodus of them orange in proximal half. It is easily distinguished by the living coloration.

Colour in alcohol. Carapace and eye-stalk whitish. Cheliped light brownish red. The cross-bands of dactyli of second and third legs reddish. The rest of the body whitish.

Material examined.

Takara-jima, 2ł $\delta, 1$ 우 (TK. No. 580), May 25, June 3-13, 1953 (TokiokA).

Dimensions (in $\mathrm{mm}$ ).

$\begin{array}{lccc} & \hat{o} & \hat{\delta} & \text { ㅇ } \\ \text { c. } 1 . & 7.5 & 5.5 & 3.8 \\ \text { c. b. } & 5.0 & 4.0 & 3.0\end{array}$

Distribution. Widely distributed in the Indo-Pacific region. Takara-jima is the northern limit of this species, and this is the first record in Japan.

\section{Calcinus latens (RANDALL, 1839)}

(Figs. 20-21)

New Jap. name: Usumurasaki-sangoyadokari

Calcinus latens StimPSon 1858, p. $85 ; 1907$, p. 208-Loo Choo (Okinawa-Hontō).

Calcinus latens ORTMANN 1892, p. 293-Amami-Oshima.

Calcinus latens TERAO 1913a, p. 592, f. 2, 2a-Naha, Okinawa-Hontō.

Description. Eye-stalk excluding eye as long as antennular peduncle, and distinctly longer than antennal peduncle. Antennal acicle with five to six spinules, one of them on outer margin, the others on inner one, reaching beyond the proximal end of the last joint of antennal peduncle. Ophthalmic scale with three spinules at the tip; it is easily distinguished from the allied species, C. terrae-reginae.

Cheliped smooth, unequal; the left one a little larger than the right. The oblique groove on outer surface of the left wrist distinct; the upper borders of palm and movable finger with granules in a line; wrist, palm and fingers furnished with fine, coarse granules. The shape and ornamentation of right cheliped are similar to those of the left one.

Second and third legs are longer than cheliped; carpus with a spine at distal end of upper border; propodus and dactylus with a few tufts of bristles.

Colour in life. Carapace pale bluish. Eye-stalk white in distal half, but its basal half dark purple. Antennule and antenna brown. Cheliped pale bluish; wrist and distal third of merus marked with a dark purplish brown cross-band. Dactylus of second and third legs marked with a dark purplish brown cross-band at the base; the rest of the surface, however, is washed with pale blue.

Colour in alcohol. Specimens have been preserved in alcohol for nine months. The basal half of eye-stalk, wrist and merus of cheliped purplish. The proximal half of dactylus of second and third legs light brown red. The rest of the body of a white colour. 


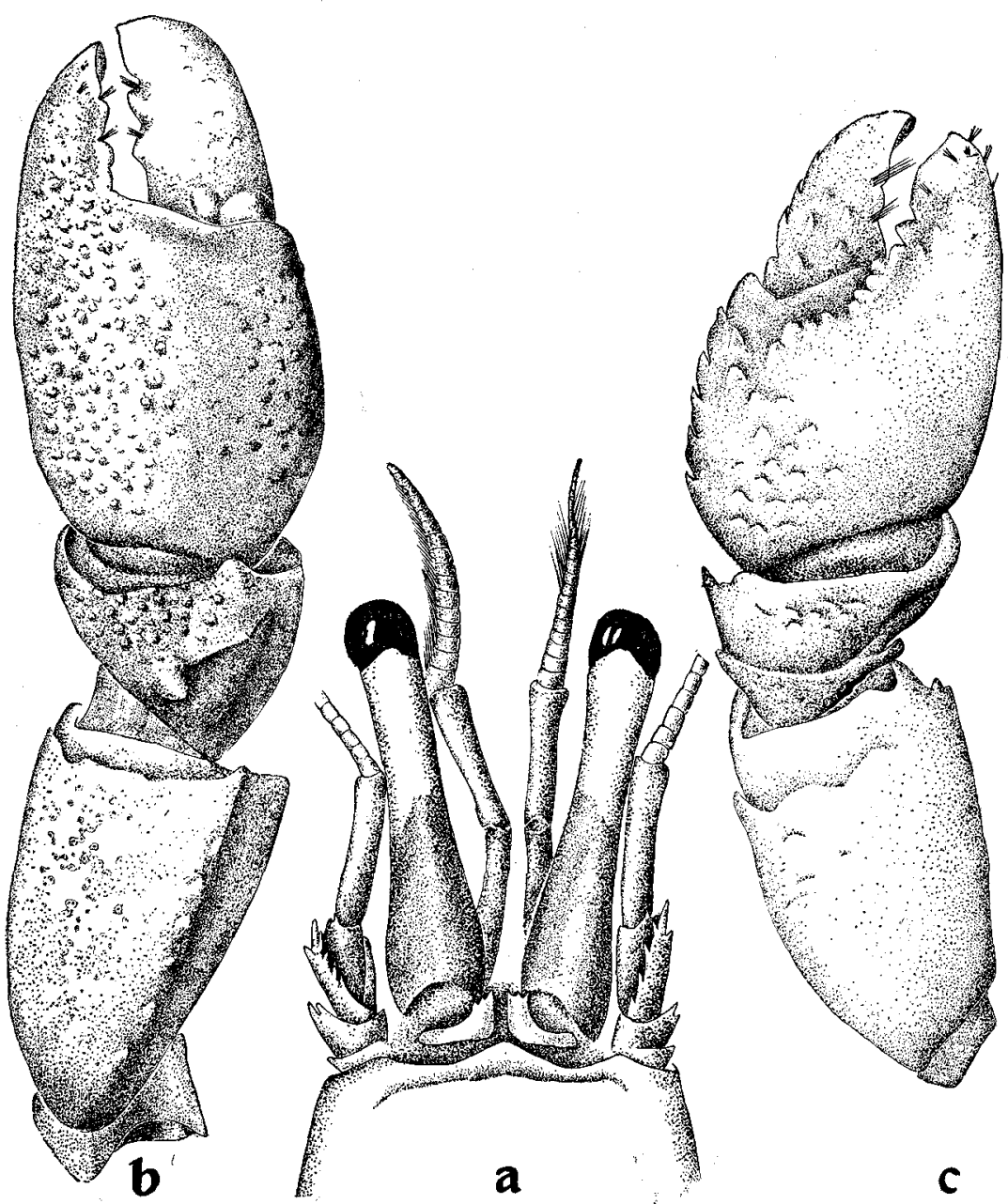

Fig. 20. Calcinus latens (RANDALI).

a, Frontal region, $\times 16$. b, upper view of left cheliped, $\times 16$. c, lower view of the same, $\times 16$.

Material examined.

Takara-jima, 2 ô $\hat{o}, 1$ ovig. 우 (TK. No. 581), May 26-June 1, 1953 (ToKIoKA). Dimensions (in $\mathrm{mm}$ ).
के
ô ovig. 우
c. $1 . \quad 6.8 \quad 5.5 \quad 5.4$
c. b. $5.0 \quad 4.0 \quad 4.2$

Distribution. A widely distributed Indo-Pacific species. The northern-most locality is Takara-jima. 


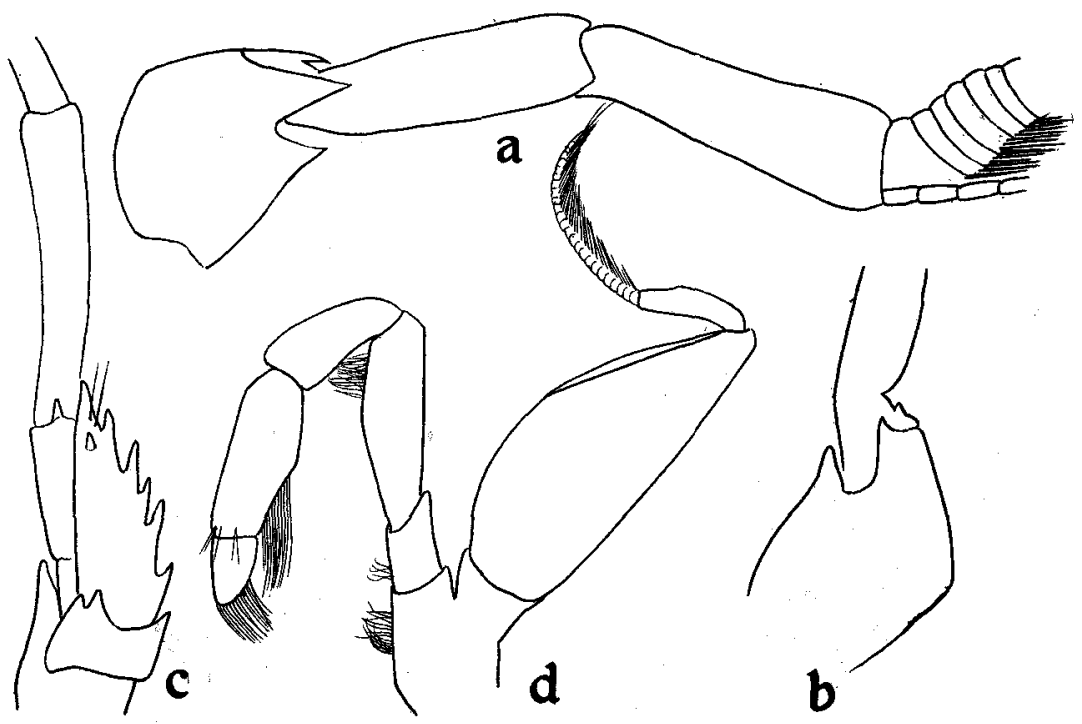

Fig. 21. Calcinus latens (RANDALI).

a, Lateral view of left antennule, $\times 40$. b, lower view of coxopodite of the same, $\times 40$. c, upper view of left antenna, $\times 40$. d, lower view of left third maxilliped, $\times 25$.

\section{Family COENOBITIDAE Ortmann, 1892}

\section{Coenobita rugosus H. Milne Edwards, 1837}

(Figs. 22-23)

Jap. name: Naki-okayadokari

Coenobita rugosa H. Milne Edwards 1837, p. 241-Indian Ocean (type locality).

Coenobita rugosa DE HAAN 1849, p. 212-Japan.

Cenobita rugosa STIMPSON 1858, p. 70-Pacific Ocean.

Coenobita rugosa OrTMANN 1892, p. 317, pl. 12, f. 22-Amami-Oshima; Indischer Ocean, Südsee, Tahiti, Neu-Hannover.

Coenobita rugosa StIMPSON 1907, p. 199-Bonin Is.; Tahiti.

Coenobita rugosa TERAo 1912, p. 104-Bonin Is.

Coenobita rugosa Terao 1913, p. 389-Oshima, Prov. Izu; Okinawa-Hontō; Tamsui, Formosa; Bonin Is.

Coenobita rugosus BALss 1913, p. 69-Nagasaki ; Tamsui, Takao, Formosa.

Coenobita rugosus MAKI et TsuchIYA 1923, p. 108, pl. 9, f. 6-Shinchiku, Kelung, Formosa.

Coenobita rugosus Takahashi 1934, p. 510, f. 2-Formosa, Kōtōsho (Botel Tobago I.), Kashōtō (Samasana I.).

Coenobita rugosus YAMAGUCHI 1938 , p. 163 -Kikai I. $\left(28^{\circ} 20^{\prime}\right.$ N.; $130^{\circ}$ E. $)$.

Coenobita rugosa Mryake 1951, p. 135-Nada, Seto, Shirahama, Prov. Kii.

Cenobita purpurea StIMPSON 1858, p. 83 ; 1907, p. 198-Bonin Is.; "Amakirrima” (Kerama-Group, near Okinawa-Hontō).

Coenobita perlata var. purpurea MELIN 1939, p. 54-Port Lloyd, Bonin Is. (Futami, Ogasawara Is.). 
Material examined.

Nakano-shima, May 25, June 3-13, 1953.

$4 \hat{s}$ o (a, b, c, d) 4 우 우 (e, f, g, h) (TK. No. 582), collected by TokiokA;

$1 \hat{\delta}(\mathrm{i}), 1$ 㝏 $(\mathrm{j})$, collected by Mтуамото.

Takara-jima, May 26-June 1, 1953.

$3 \hat{\delta} \hat{o}(\mathrm{n}, \mathrm{o}, \mathrm{p}), 4$ 우 우 (q, r, s, t) (TK. No. 583, 584), collected by ToKioKA ;

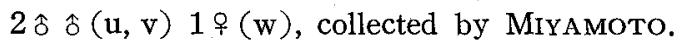

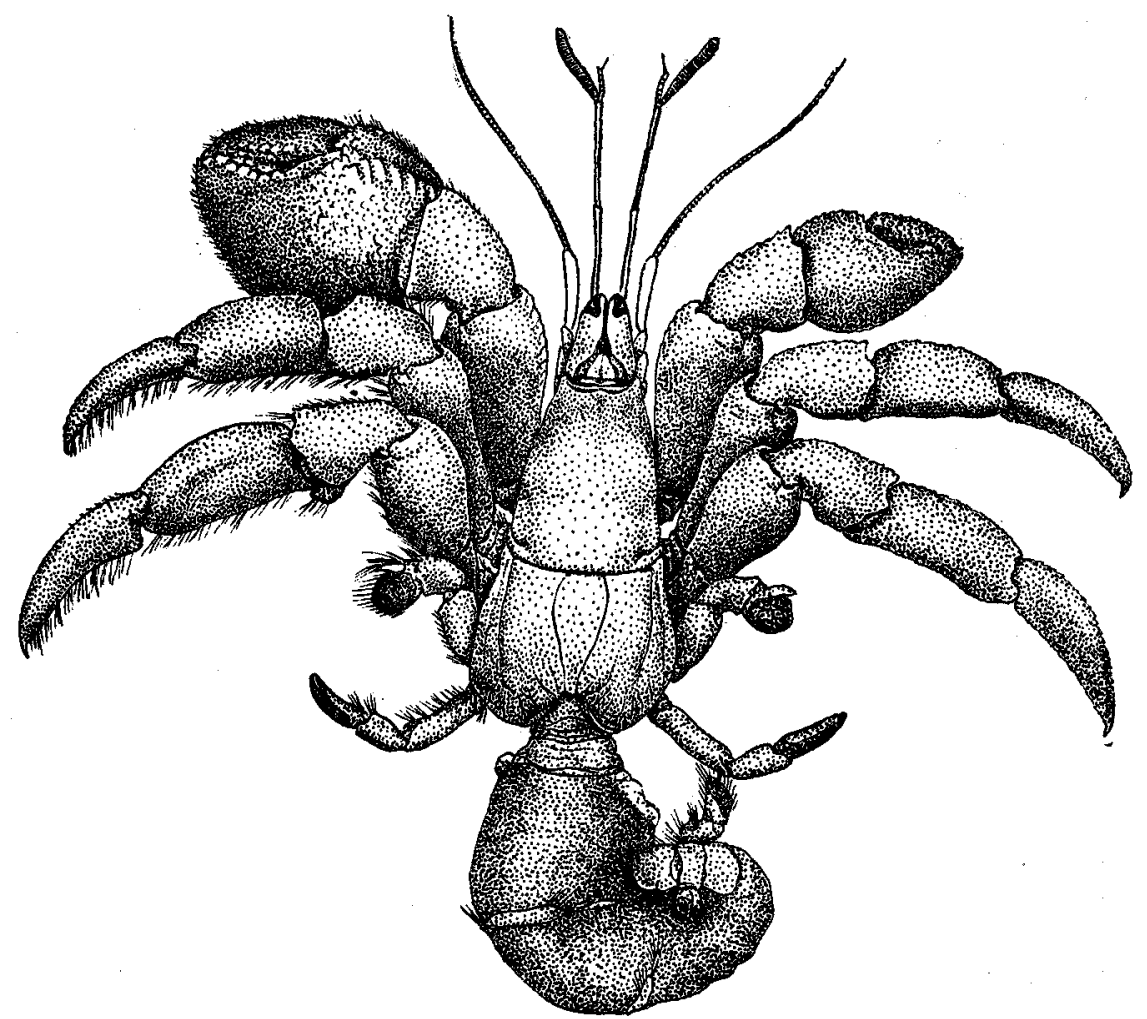

Fig. 22. Coenobita rugosus $\mathrm{H}$. MILNE EDWARds, $\times 2$.

Dimensions (in $\mathrm{mm}$ ).

\begin{tabular}{lccccccccccc} 
& \multicolumn{10}{c}{ Males } \\
& $\mathrm{k}$ & $\mathrm{a}$ & $\mathrm{i}$ & $\mathrm{u}$ & $\mathrm{n}$ & $\mathrm{b}$ & \multicolumn{1}{c}{$\mathrm{c}$} & $\mathrm{d}$ & $\mathrm{p}$ & \multicolumn{1}{c}{$\mathrm{o}$} & \multicolumn{1}{c}{$\mathrm{v}$} \\
c. l. & 5.3 & 7.3 & 8.0 & 8.9 & 9.8 & 14.5 & 16.0 & 16.5 & 21.0 & 22.0 & 33.8 \\
c. b. & 5.0 & 5.0 & 5.2 & 5.2 & 6.0 & 10.0 & 11.0 & 11.2 & 13.6 & 14.0 & 19.0 \\
r. c. p. ${ }^{1)}$ & 1.0 & 2.0 & 2.1 & 3.8 miss. & 6.8 & 7.2 & 7.1 & 7.0 & 6.5 & 12.0 \\
l. c. p. ${ }^{2)}$ & 0.8 & 1.2 & 1.8 & 2.0 miss. & 4.1 & 4.3 & 5.0 & 4.3 & 3.6 & 8.0
\end{tabular}

1) right coxal process; 2) left coxal process. 


$\begin{array}{ccccccccccccc} & \mathrm{l} & \mathrm{e} & \mathrm{f} & \mathrm{m} & \mathrm{q} & \mathrm{r} & \mathrm{s} & \mathrm{t} & \mathrm{g} & \mathrm{h} & \mathrm{j} & \mathrm{w} \\ \text { c. } 1 . & 4.0 & 5.2 & 6.0 & 6.3 & 7.0 & 7.0 & 8.3 & 9.8 & 11.0 & 11.3 & 14.0 & 17.2 \\ \text { c. b. } & 2.8 & 3.5 & 4.0 & 4.0 & 4.0 & 4.3 & 5.0 & 7.1 & 8.0 & 9.2 & 9.0 & 11.0\end{array}$

Remarks. After closer examination, the following variations of the coxal elongation of the fifth leg of the male and coloration were observed.

In smaller individuals up to $7 \mathrm{~mm}$ in length of carapace, the right coxal process is almost equal to the left one as in the examples (a, $\mathrm{k}$ ) illustrated in the Fig. 23, a,
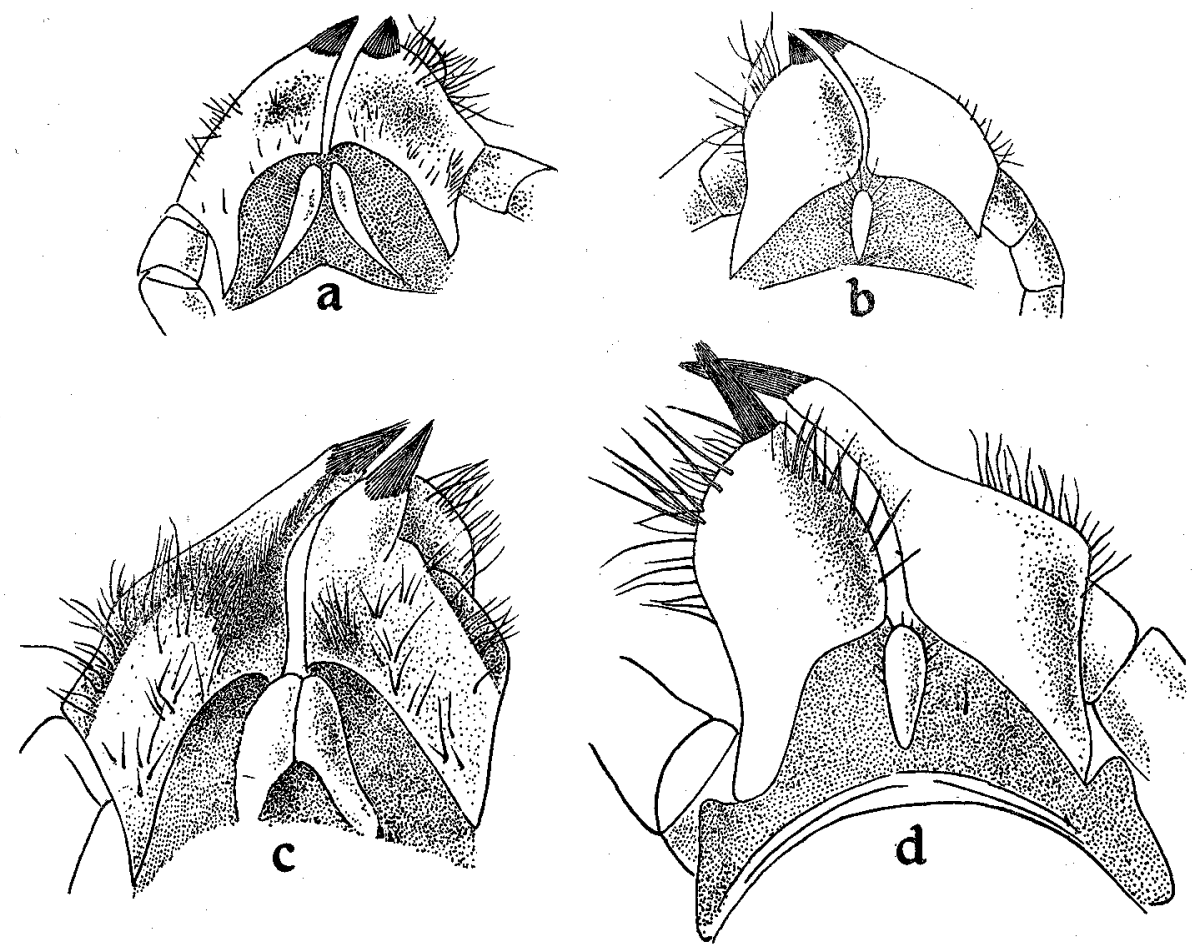

Fig. 23. Coenobita rugosus $\mathrm{H}$. MILNE EdwaRds. a, Lower view of the coxal process of the specimen $a, \times 12$. b, upper view of the same, $\times 12$. c, lower view of the coxal process of the specimen $n$, $\times 8$. $d$, lower view of the same, $\times 8$.

$\mathrm{b}$; in larger specimens more than $8 \mathrm{~mm}$ in length of carapace, the right process is distinctly longer than the left as in Fig. 23, c, d.

The following description is based upon one female of olive colour $(j, 14 \mathrm{~mm}$ in length of carapace) from Nakano-shima. General ground-colour of dorsal face orangeyellow, the ventral face lighter. Antennule red, antenna dark brown. Carapace and legs marked with dark brown patches or spots; fingers of chelipeds, dactyli of second and third legs bluish with dark brown spots distally. 
Most of all smaller specimens up to $15 \mathrm{~mm}$ in length of carapace have the similar colour. It has, however, nearly gone in alcohol preserved in 14 months. Legs and carapace of an olive colour with dark reddish-brown patches or spots.

In larger specimens more than $15 \mathrm{~mm}$ in length of carapace, legs and carapace become purplish. The living colour of a male ( $\mathrm{v}, 33.8 \mathrm{~mm}$ in length of carapace) described below. Eye-stalk bluish purple; peduncles of antennule and antenna light blue; flagella light greenish brown. Legs and carapace of a deep purplish colour with red or red-brown spots on left cheliped.

The living colour of C. purpurea Stimpson (1858) from Kerama Group "Amakirrima" seems to be similar one mentioned above. According to YAMAGuchI (1938), general body-colour of C. rugosus which is pale red in the adolescent stage becomes purple or gray during the growth-period.

Distribution. The most widespread land hermit-crab in the Indo-Pacific area. The northern limit of this species is Nada, Prov. Kii, Japan.

\section{LITERATURE}

Alcock, A. 1905. Catalogue of the Indian Decapod Crustacea in the collection of the Indian Museum. II. Anomura, Fasc. 1, Pagurides, Calcutta. 1-197, pls. 1-16.

BALss, H. 1913. Ostasiatische Decapoden. I. Die Galatheiden und Paguriden. Abh. K. B. Ak. Wiss. München, math.-phys. K1., Suppl. 2 (9) : 1-85, pls. 1-2. 1914. Ditto, II. Die Natantia und Reptantia. Ibid. Suppl. 2 (10): 1-101, pl. 1.

Borradaile, L. A. 1898. On some Crustaceans from the South Pacific. II. Macrura anomala. Proc. zool. Soc. London, 1898 : 457-468, pl. 36.

1906. Marine Crustaceans. XIII. The Hippidea, Thalassinidea and Scyllaridea. In : GARDINEP's The fauna and Geography of the Maldive and Laccadive Archipelagoes. Cambridge. 2: 750-754, pl. 58 .

BurtendiJK, A. M. 1937. Biological results of the Snellius Expedition. IV. The Paguridea of the Snellius Expedition. Temminckia, Leiden, 2: 251-280.

DANA, J. D. 1852. Crustacea.-United States Exploring Expedition during the years 1838-1842 $\cdots \cdots .13: 1-1620 ; 1855$, pls. $1-96$.

Estampador., E. P. 1939. A check list of Philippine Crustacean Decapods. Philipp. J. Sci., Manila., $62(4): 465-559$.

Fize, A. et R. SERÈnE 1955. Les Pagures du Vietnam. Notes Inst. Oceanogr. Nhatrang, VietNam, (45) : i-ix, 1-228, text-figs. 1-35, pls. 1-6.

Forest, J. 1953. Crustacés Décapodes Marcheurs des îles de Tahiti et des Tuamotu. I. Paguridea. Bull. Mus. nat. Hist. nat., sér. 2, 25 (5) : 441-450.

DE HAAN, W. 1833-1850. Crustacea. In : P. F. Siebold, Fauna Japonica, Batavia. 1-244, pls. 1-55.

HASWElL, W. A. 1882. Catalogue of the Australian stalk- and sessile-eyed Crustacea, Sydney, 1-324, pls. $1-4$.

HENDERSON, J. R. 1888. Report on the scientific results of the Voyage of H. M. S. Challenger, Zool. 27. Anomura, 1-221, pls. 1-21.

MaKr, M. and H. TsuchiYA 1923. A monograph of the Decapod Crustaceans from Formosa (in Japanese). Dep. Agric. Gov. Res. Inst. Formosa, Rep. 3: 1-215, pls. 1-24.

DE MAN, J. G. 1887. Bericht über die von Herrn Dr. J. BRock im indischen Archipel gesam. melten Decapoden und Stomatopoden. Arch. Naturgesch, Berlin, 53: 215-600, pls. 7-22.

1888. Report on the Podophthalmus Crustacea of the Mergui Archipelago. J. Linn. Soc. London, Zool., 22 : 1-312, pls. 1-19. 
1902. Die von Herrn Prof. KüKEnTmal im Indischen Archipel gesammelten Dekapoden und Stomatopoden. Abh. Senkenberg naturforsch. Ges., Frankfurt a.M., 25 (3): 467-929, pls. 19-27.

MeliN, G. 1939. Paguriden und Galatheiden von Prof. Dr. Sixten Bocks Expedition nach den Bonin-Inseln 1914. K. svensk. Vetensk. Ak. Handl., Stockholm, Tredje ser., 18 (2) : 1-119.

MilnE EDWAR.DS, H. 1836. Observations zoologiques sur les Pagures et description d'un nouveau genere de la tribu des Paguriens. Ann. Sci. nat. Zool., Paris, sér. 2, 6: 257-288, pls. 13-14. 1837. Des Decapodes Anomoures. In: Histoire naturelle des Crustacés, comprenant l'Anatomie, la Physiologie et la Classification de ces animaux. Paris, 2 : 168-277.

MrYAKE S. 1943. Studies on the crab-shaped Anomura of Nippon and adjacent waters. J. Dep. Agric. Kyusyu Imp. Univ., Fukuoka, 7 (3): 49-158.

- 1951. A check list of Anomura from Prov. Kii, Japan (in Japanese, mimeographed) Nanki-Seibutsu, 2 (3-4): 127-140.

Nakazawa, K. 1927. Anomura. In: Nippon Dôbutsu Zukan (Illustrated Encyclopedia of the fauna of Japan), Tokyo (in Japanese). 1035-1051, figs. 1993-2025.

NAKAZA.WA, K. and S. MIYAKE 1947. Ditto, ist revised ed. 731-750, figs. 2115-2171. 1949. Ditto, 2nd revised ed. 731-752, figs. 2115-2177.

Nobilt, G. 1906. Faune Carcinogique de la Mer Rouge. Decapodes et Stomatopodes. Ann. Sci. nat. Zool., Paris, sér. 9, 4 : 1-347, pls. 1-11.

Ortmann, A. E. 1892. Die Decapoden-Krebse des Strassburger Museums. IV. Die Abtheilungen Galatheidea und Paguridea. Zool. Jb. Syst., Jena, 6: 241-326, pls. 11-12.

Pesta, O. 1914. Crustacea. II. Decapoda (mit Ausschluß der Brachyura) und Stomatopoda aus Samoa. Denkschr. Ak. Wiss. Wien, math.-naturw. Kl., 89: 673 683.

ShinNo, S. M. 1933. Bopyrids from Tanabe Bay. Mem. Coll. Sci. Kyoto Imp. Univ., ser. B, 8 (3): $249-300$.

STIMPSON, W. 1858. Prodromus descriptionis animalium evertebratorum, quae in Expeditione ad Oceanum Pacificum Septentrionalem. VII. Crustacea Anomoura. Proc. Ac. nat. Sci., Philadelphia, 63-90.

1907. Report on the Crustacea (Brachyura and Anomura) collected by the North Pacific Exploring Expedition, 1853-1856. Smithson. Miscell. Coll., Washington, 49: 1-240, pls. $1-26$.

TAKahashi, S. 1934. On the land hermits (Coenobitidae) in Formosa (in Japanese). Trans. nat. Hist. Soc. Formosa, 21 (135) : 506-507.

TERAO, A. 1913. A catalogue of hermit-crabs found in Japan (Paguridae excluding Lithodidae), with description of four new species. Annot. Zool. Jap., Tokyo, 8: 355-391. 1913-1914. Hermit-crabs of Japan (in Japanese). Zool. Mag., Tokyo. 25 : 591-594; 26 : 109-110, 181-182.

YAMAGUCHI, S. 1938. Spawning and development of Coenobita rugosus (in Japanese with English résumé). Bult. Sci. Fakult. Terkurt. Kjuŝu Imp. Univ. Hukuoka, 8 (2) : 163-177, pl. 2. 